Maurer School of Law: Indiana University

Digital Repository @ Maurer Law

2010

\title{
Is the PCAOB a "Heavily Controlled Component" of the SEC?: An Essential Question in the Constitutional Controversy
}

Donna M. Nagy

Indiana University Maurer School of Law, dnagy@indiana.edu

Follow this and additional works at: https://www.repository.law.indiana.edu/facpub

Part of the Constitutional Law Commons, and the Securities Law Commons

\section{Recommended Citation}

Nagy, Donna M., "Is the PCAOB a "Heavily Controlled Component" of the SEC?: An Essential Question in the Constitutional Controversy" (2010). Articles by Maurer Faculty. 35.

https://www.repository.law.indiana.edu/facpub/35

This Article is brought to you for free and open access by the Faculty Scholarship at Digital Repository @ Maurer Law. It has been accepted for inclusion in Articles by Maurer Faculty by an authorized administrator of Digital Repository @ Maurer Law. For more information, please contact rvaughan@indiana.edu. 


\title{
ARTICLES
}

\section{IS THE PCAOB A "HEAVILY CONTROLLED COMPONENT" OF THE SEC?: AN ESSENTIAL QUESTION IN THE CONSTITUTIONAL CONTROVERSY}

\author{
Donna M. Nagy•
}

The U.S. Supreme Court recently heard oral arguments in Free Enterprise Fund v. Public Company Accounting Oversight Board, ' described as "the most important separation-of-powers case regarding the President's appointment and removal powers to reach the courts in the last 20 years." Established by Congress as the cornerstone of the Sarbanes-Oxley Act of 2002 ("SarbanesOxley" or the "Act"), ${ }^{3}$ the Public Company Accounting Oversight Board (the "PCAOB" or the "Board") was structured as "a strong, independent board to oversee the conduct of the auditors of public companies." Its principal mission was to prevent the type of auditing failures that contributed to the

* C. Ben Dutton Professor of Law, Indiana University Maurer School of Law-Bloomington. I presented this Article at a symposium, The Past, Present, and Future of the SEC, held at the University of Pittsburgh School of Law on October 16, 2009, and I am grateful to Professors Douglas Branson and Peter $\mathrm{Oh}$, the student editors, and my fellow symposium participants. The Article also has benefited from insights and comments by Professors Alfred Aman, John Applegate, Hannah Buxbaum, Kent Greenfield, Leandra Lederman, Margaret Sachs, Tuan Samahon, Faith Stevelman, and Joseph Tomain, and from presentations made at Boston College Law School and the 2009 Meeting of the Law and Society Association. Marshall Magaro provided excellent research assistance.

1. Free Enterprise Fund v. Public Co. Account. Over. Bd., 537 F.3d 667 (D.C. Cir. 2008), cert. granted, 77 U.S.L.W. 3625 (U.S. May 18, 2009) (No. 08-861).

2. Id. at 685 (Kavanaugh, J., dissenting).

3. Sarbanes-Oxley Act of 2002, Pub. L. No. 107-204, 116 Stat. 745 (2002) (codified in scattered sections of 15, 18, 28, and 29 U.S.C.). The Act contains eleven titles; "The Public Company Accounting Oversight Board" is Title I (15 U.S.C. $\S \S 7211-7219)$.

4. S. REP. No. 107-205, at 2 (2002). 
scandals at Enron, WorldCom, and numerous other public companies in the period leading up to the passage of the Act.

The PCAOB's unique design as a private-sector corporation with vast regulatory powers sparked controversy from the start. Notwithstanding Sarbanes-Oxley's explicit provision that " $[t]$ he Board shall not be an agency or establishment of the United States Government," my first article on the PCAOB contended that the Board is part of the federal government, at least for purposes of the Constitution. ${ }^{6}$ In the course of the Free Enterprise Fund litigation, the PCAOB and the Department of Justice ("DOJ") as intervenor have conceded that the PCAOB is subject to constitutional scrutiny.? Accordingly, the controversy now centers on whether the PCAOB's structure complies with the Appointments Clause and the doctrine of separation of powers. That structure has been called into question because the five members who head the PCAOB are neither appointed nor removable by the President. Instead, PCAOB members are appointed for fixed; five-year terms by the Securities and Exchange Commission (the "SEC" or "Commission"), an independent regulatory agency that is itself insulated from direct presidential control. Moreover, PCAOB members are removable only by the SEC and only for willful or unjustifiable transgressions. On behalf of a group of corporate and securities law scholars, I filed an amici curiae brief supporting the Petitioners' position that the PCAOB's structure is unconstitutional. ${ }^{8}$ The brief made clear that while we applauded Congress's decision to establish a new regulator to oversee the auditors of public companies, we were concerned that the particular design accorded the PCAOB substantial discretion and autonomy without imposing constitutionally sufficient accountability. ${ }^{9}$

No matter how the Supreme Court rules on the constitutional issues, its decision in Free Enterprise Fund is bound to have far-reaching implications for the future of securities enforcement and financial regulation in general. If the PCAOB's structure is upheld by the Court, we can expect Congress to create many more independent regulators answerable in only limited respects

5. 15 U.S.C. $\$ 7211$ (b) (2006).

6. See Donna M. Nagy, Playing Peekaboo With Constitutional Law: The PCAOB and Its Public/Private Status, 80 Notre Dame L. Rev. 975 (2005).

7. See Free Enterprise Fund v. Public Co. Account. Over. Bd., 2007 WL 891675, at *3 (D.D.C. 2007) (stating " $[t]$ he parties agree that, at least for purposes of these motions, PCAOB should be considered a governmental entity, and so it shall be").

8. Brief of Amici Curiae Law Professors, Donna M. Nagy et al., Free Enterprise Fund v. Public Co. Account. Over. Bd. (No.08-861) (filed Aug. 3, 2009), 2009 WL 2406371.

9. Id. at 1. Much of what follows builds on the arguments in that Brief, but I am speaking only for myself in this Article. 
to the SEC or other independent regulatory agencies. Congress has already been urged to create PCAOB-like entities to oversee credit rating agencies ${ }^{10}$ and the mutual fund industry. ${ }^{11}$ The possibility of additional regulators modeled on the PCAOB is worrisome because the PCAOB's structure renders it less accountable to the public than traditional independent regulatory agencies (whose members are appointed by the President with advice and consent from the Senate, and are removable for cause by the President). Moreover, regulators designated as "private" can operate with substantially less transparency because statutes such as the Administrative Procedures Act (APA), the Freedom of Information Act (FOIA), and the Government in Sunshine Act generally apply only to federal agencies.

Significant consequences will also flow from a Court ruling that the PCAOB's structure is unconstitutional. Although Congress likely would act quickly to restructure the $\mathrm{PCAOB}$, either as a regulator with presidentially appointed board members who are removable for-cause by the President or as a unit within the SEC with members who are SEC employees, the legislative process could open the door to additional changes. ${ }^{12} \mathrm{~A}$ ruling that the PCAOB is unconstitutional may also subject the Municipal Securities Rulemaking Board (MSRB) and the Securities Investor Protection Corporation (SIPC) to new constitutional scrutiny, since both the MSRB and the SIPC share the PCAOB's status as a congressionally created regulator in the private sector. A broad holding by the Court could raise questions about the level of independence asserted by even long-standing federal agencies such as the

10. See Frank Partnoy, Rethinking Regulation of Credit Rating Agencies: An Institutional Investor Perspective, White Paper prepared for the Council of Institutional Investors, April 2009, at 8, available at http://www.cii.org/UserFiles/file/CRAWhitePaper04-14-09.pdf (proposing the creation of "a single independent Credit Rating Agency Oversight Board (CRAOB), with a structure and mission similar to that of the Public Company Accounting Oversight Board (PCAOB)").

11. See John C. Coates, Reforming the Taxation and Regulation of Mutual Funds: A Comparative Legal and Economic Analysis, 1 J. LEGAL ANALYSIS 591, 657-58 (2009) (bemoaning the lack of resources available to the SEC's Division of Investment Management, and suggesting, among other possibilities, moving Investment Management "outside of the SEC altogether" into a new entity modeled on the PCAOB); Mutual Funds: Who's Looking Out for Investors? Hearings Before the Subcomm. on Capital Markets, Insurance, and Government Sponsored Enterprises of the H.R. Comm. on Financial Services, 108th Cong. 157-58 (2003) (statement of Professor Mercer Bullard) (recommending that Congress create a Mutual Fund Oversight Board modeled on the PCAOB). See also Mutual Fund Investor Protection Act of 2003, S. 1958, 108th Cong. § 201, 149 Cong. Rec. 15977, 15984 (2003) (introducing legislation from Senators Thomas Daschle, Edward Kennedy, and John Kerry that, among other things, would have established a "Mutual Fund Oversight Board").

12. See John C. Coffee, Jr., Changes Needed Before Fed is Given Regulatory Mission, N.Y. L.J. 5 (July 16, 2009) (noting "the number of interest groups intensively eager to add their small change to Sarbanes-Oxley"). 
Federal Reserve, an entity often described as "the most independent of all federal agencies and the least subject to congressional oversight."13

In addition, no matter what constitutional verdict is ultimately rendered for the PCAOB, the Court's decision may affect the self-regulatory organizations (SROs) in the securities industry, such as New York Stock Exchange (NYSE) and the Financial Industry Regulatory Authority (FINRA) (formerly, the National Association of Securities Dealers (NASD)). Indeed, because Congress modeled the SEC's oversight of the PCAOB on the statutory provisions applicable to the NYSE and NASD, the Court is likely to examine closely the relationship between those SROs and the SEC in the course of its analysis of the PCAOB.

Securities law scholars are generally reluctant to delve into debates about constitutional and administrative law. Yet Free Enterprise Fund raises a threshold issue that calls out for securities law expertise. As this Article will show, the D.C. Circuit's 2-1 decision upholding the constitutionality of the $\mathrm{PCAOB}^{14}$ was predicated on the majority's determination that the PCAOB was a "heavily controlled component" of the SEC,${ }^{15}$ with the Board's exercise of its statutory duties "subject to check by the Commission at every significant step."16 If the D.C. Circuit's depiction of the PCAOB is incorrect, as this Article contends, then the arguments supporting the PCAOB's constitutionality fall with it. PCAOB members acting with significant discretion and autonomy outside of the SEC's control would be "principal officers" who, pursuant to the Appointments Clause, must be appointed by the President with the advice and consent of the Senate. And as "principal officers" performing significant executive functions, PCAOB members must be removable for cause by the President. Securities scholars thus have much to contribute to the constitutional analysis of the PCAOB. ${ }^{17}$

13. David Zaring, In Defense of the Fed's Independence, Washington Post-Hearing Online Forum, July 10, 2009, http://voices.washingtonpost.com/hearing/2009/07/in_defense_independent_fed.html.

14. Free Enterprise Fund v. Public Co. Account. Over. Bd., $53 \overline{7}$ F.3d 667 (D.C. Cir. 2008). The full D.C. Circuit, by a 5-4 vote, denied rehearing en banc.

15. Id. at 680 .

16. Id. at 673. See also id. at 675 (emphasizing the Board's role as a "specialized component of the Commission").

17. For recent essays by distinguished constitutional and administrative law scholars, see Peter L. Strauss, Free Enterprise Fund v. Public Company Accounting Oversight Board, 62 VAND. L. REv. EN BANC 51 (2009); Harold H. Bruff, Bringing the Independent Agencies in from the Cold, 62 VAND. L. REV. EN BANC 63 (2009); Gary Lawson, The "Principal" Reason Why the PCAOB is Unconstitutional, 62 VAND. L. Rev. EN BANC 73 (2009); Richard H. Pildes, Putting Power Back into Separation of Powers Analysis: Why the SEC-PCAOB Structure is Constitutional, 62 VAND. L. REV. EN BANC 85 (2009); Steve G. Calabresi \& Christopher S. Yoo, Remove Morrison v. Olson, 62 VAND. L. Rev. EN BANC 103 (2009). 
The essential role for securities scholars in the debate over the PCAOB's constitutionality became even clearer during the oral argument before the Supreme Court. At the outset of the Government's argument, Solicitor General Elena Kagan emphasized that "resolution of this case" turns on a "simple syllogism."18 Her major premise was that the "President has constitutionally sufficient control over the SEC" and her minor premise was that "[ $t]$ he SEC has comprehensive control over the Accounting Board." conclusion was that "the President has constitutionally sufficient control over the Accounting Board." ${ }^{20}$ I completely agree that the constitutionality of the PCAOB turns on the validity of this syllogism. This Article, however, seeks to show that the syllogism's minor premise is grounded in an inaccurate view of the PCAOB-SEC relationship.

The analysis in this Article proceeds in three parts. Part I presents a snapshot of the PCAOB and examines the D.C. Circuit's majority and dissenting opinions. Part II challenges the panel majority's characterization of the PCAOB as a "heavily controlled component" of the SEC and explains why the PCAOB must instead be regarded as an independent regulatory entity in its own right. In so doing, Part II examines Sarbanes-Oxley's text, its legislative history, the SRO model on which the PCAOB was patterned, and insights derived from the constitutional doctrine of nondelegation. Building on the view that PCAOB members exercise significant discretion and autonomy notwithstanding the SEC's oversight and enforcement authority, Part III then analyzes the PCAOB under the Appointments Clause and the doctrine of separation of powers. It concludes that the PCAOB's structure violates the Constitution in both respects. Part III also explains why neither the regulated nor protected public is well served by a congressionally created "private" regulator such as the PCAOB with double-decker independence.

18. See Transcript of Oral Argument, Free Enterprise Fund v. Public Company Accounting Oversight Board (No. 08-861), at *30, 2009 WL 45715555.

19. Id.

20. Id. 


\section{Part One: A Snapshot of the PCAOB and the Constitutional CONTROVERSY}

\section{A. The PCAOB's "Strange" Design}

In establishing the PCAOB "to oversee the audit of public companies,"21 Congress recognized that it was creating a "strange kind of entity."22 As Senator Phil Gramm explained: "We want it to be private, but we want it to have governmental powers. We have tried to structure it in ways to try to accommodate this." ${ }^{23}$

There is no dispute that Sarbanes-Oxley, enacted in the wake of the massive accounting and corporate governance scandals at Enron, WorldCom, and other public companies, vested the PCAOB with broad governmental powers and responsibilities. These powers and responsibilities encompass substantial enforcement, rulemaking, and adjudicative functions, ${ }^{24}$ and include the authority to register accounting firms that audit public companies; ${ }^{25}$ enact rules setting standards for auditing, quality control, ethics, and independence, ${ }^{26}$ inspect on a yearly basis the nation's largest accounting firms and inspect other firms at least once every three years; ${ }^{27}$ investigate accounting firms and their associated persons for possible violations of PCAOB rules or the federal securities laws, ${ }^{28}$ and impose discipline for established violations through a range of sanctions including censures, temporary suspensions, permanent bars, and substantial monetary fines. ${ }^{29}$ Willful violations of PCAOB rules may be prosecuted by the DOJ as federal crimes. ${ }^{30}$ In addition, the Act authorizes the PCAOB to set its own budget, and

21. 15 U.S.C. $\$ 7211$ (a) (2006).

22. 148 CONG. REC. 12,122 (2002) (statement of Sen. Gramm).

23. Id.

24. See U.S. Gen. Accounting Office, No. GAO-03-339, Securities and Exchange Commission: Actions Needed to Improve Public Company Accounting Oversight Board Selection Process 1 (2002) (noting that "[t]he PCAOB was given broad powers to inspect the accounting firms performing [public company] audits, set rules and standards for such audits, and impose meaningful sanctions if warranted").

25. 15 U.S.C. $\S 7212(2006)$.

26. 15 U.S.C. $\$ 7213(2006)$.

27. 15 U.S.C. $\$ 7214(2006)$.

28. 15 U.S.C. $\S 7214$.

29. 15 U.S.C. $\$ 7214$. Sabanes-Oxley further authorizes the PCAOB to "perform such other duties or functions as the Board (or the Commission, by rule or order) determines are necessary or appropriate ... to carry out this Act, in order to protect investors, or to further the public interest." 15 U.S.C. $\$ 7211$ (c)(5) (2006).

30. Securities Exchange Act of 1934, 15 U.S.C. § 32(a) (2006), 15 U.S.C. $\S 78 \mathrm{ff}(\mathrm{a})(2006)$ (applicable through Section 3(b) of the Sarbanes-Oxley Act, 15 U.S.C. $\S$ 7202(b) (2006)). 
to fund that budget through the imposition of an "accounting support fee" levied on public companies. ${ }^{31}$

The statutory text also evidences Congress's clear intention to vest the PCAOB's broad regulatory powers in a private, nonprofit corporation. In a subsection captioned "status," Congress provided that:

The Board shall not be an agency or establishment of the United States Government and, except as otherwise provided in this Act, shall be subject to, and have all the powers conferred upon a nonprofit corporation by, the District of Columbia Nonprofit Corporation Act. No member or person employed by, or agent for, the Board shall be deemed to be an officer or employee of or agent for the Federal Government by reason of such service. ${ }^{32}$

The PCAOB is headed by five members appointed by the SEC for fixed fiveyear terms "after consultation with the Chairman of the Board of Governors of the Federal Reserve System and the Secretary of the Treasury," with vacancies filled "in the same manner." ${ }^{\text {"33 }}$ PCAOB members can be removed from office only by the SEC and only for "good cause shown,"34 with "good cause" defined restrictively. ${ }^{35}$ Congress further provided that the SEC "shall have oversight and enforcement over the Board, as provided in this Act."

More than a decade ago, in Lebron v. National R.R. Passenger Corp. ${ }^{37}$ the Supreme Court articulated a three-part test for determining whether a corporation would be deemed a part of the federal government for purposes of constitutional law, notwithstanding statutory text to the contrary. The Lebron case involved a First Amendment challenge to actions by Amtrak, which, like the PCAOB, was established by an Act of Congress providing that the corporation "will not be an agency or establishment of the United States Government." ${ }^{\text {38 }}$ Justice Scalia, writing for himself and seven other Justices, held explicitly that "it is not for Congress to make the final determination of [a corporation's] status as a Government entity for purposes of determining the constitutional rights of citizens affected by its actions. ${ }^{39}$ The Court then concluded that Amtrak must adhere to the First Amendment because where

31. 15 U.S.C. $\$ 7219($ b)-(d) (2006). See infra notes 114-15 and accompanying text.

32. 15 U.S.C. $\$ 7211(\mathrm{~b})$.

33. 15 U.S.C. $\$ 7211(\mathrm{e})(4)$.

34. 15 U.S.C. $\S 7211(\mathrm{e})(6)$.

35. 15 U.S.C. $\$ 7217$ (d)(3) (2006). See infra notes $86-87$ and accompanying text.

36. 15 U.S.C. $\$ 7217$ (a). See infra notes $88-90$ and accompanying text.

37. Lebron v. National R.R. Passenger Corp., 513 U.S. 374 (1995).

38. Id. at 391 (quoting 45 U.S.C. $\$ 541$ (2006)).

39. Id. at 392. 
(1) "the Government creates a corporation by special law," (2) "for the furtherance of governmental objectives," and (3) "retains for itself permanent authority to appoint a majority of the directors of that corporation," that entity "is part of the Government for purposes of [the Constitution]."

Although PCAOB officials initially intimated that its status as a private corporation allowed it to operate free from the constraints of the Constitution, ${ }^{41}$ the PCAOB's congressional creation as a regulatory entity with an SEC-appointed board ultimately left the PCAOB and DOJ with no choice but to concede that, under the holding in Lebron, the PCAOB is "part of the Government" and its members are federal officers for purposes of constitutional law. ${ }^{42}$

Congress's design of the PCAOB as a "strange kind of entity" thus presents the Supreme Court with a statutory conundrum: The Court must determine whether PCAOB members are "principal officers" or "inferior officers" in the face of a congressional statute providing that PCAOB members are not federal officers. This conundrum requires the Court itself to situate the PCAOB within an organizational chart of the federal government. Only then can the Justices determine whether the Appointments Clause permits PCAOB members to be appointed by the SEC, and whether the statutory limitations on the appointment and removal of PCAOB members are consistent with the doctrine of separation of powers.

\section{B. The Decision by the D.C. Circuit}

When the D.C. Circuit attempted to place the PCAOB within an organizational chart of the federal government, the members of its three-judge panel constructed diametrically different versions. ${ }^{43}$ Judge Judith Rogers, in a majority opinion joined by Judge Janice Brown, depicted the PCAOB as a "specialized" and "heavily controlled component" of the SEC, ${ }^{44}$ with the Board's exercise of its statutory duties "subject to check by the Commission

40. Id. at 400 .

41. See Mary M. Sjoquist \& Marilyn H. Weimer, The PCAOB Takes on Enforcement, 7 WaLL ST. LAw. 1, Mar. 2004, at 1, 3-7, available at http:/www.realcoporatelawyer.com/wsl/ws10304.html (stating that the PCAOB intended to recognize good-faith assertions of the privilege against self-incrimination, but observing that as "a non-governmental entity, the Board has a strong argument that the Fifth Amendment does not apply to its processes, and thus could require registered public accounting firms or their associated persons to testify or produce documents").

42. See supra note $\mathbf{4 0 .}$

43. Free Enterprise Fund v. Public Co. Account. Over. Bd., 537 F.3d 667 (D.C. Cir. 2008).

44. Id. at 675,680 . 
at every significant step." "In sharp contrast, Judge Brett Kavanaugh's dissent regarded the PCAOB as "an independent agency appointed by and removable for cause by another independent agency."46

Several factors contributed to the majority's view that the SEC's authority over the PCAOB was "extraordinary." 47 The majority emphasized that "the Commission approves all Board rules, and may abrogate, delete, or add to them." ${ }^{\text {"48 }}$ Moreover, "[a]ll Board sanctions are subject to plenary review by the Commission, and the Commission 'may enhance, modify, cancel, reduce, or require the remission of a sanction imposed by the Board.",49 Thus, "[n]o Board rule is promulgated and no Board sanction is imposed without the Commission's stamp of approval." 50 The majority further emphasized that the SEC must approve the PCAOB's annual budget as well as the formula for the "accounting support fee" that Congress authorized the PCAOB to levy on public companies to fund its budget. ${ }^{51}$ The majority also called attention to the SEC's broad enforcement authority over the PCAOB, and highlighted the specific provisions in the Act that, in the majority's words, authorize the SEC "to limit and remove Board authority altogether." provisions, according to the majority, essentially grant the SEC "at-will removal power over Board functions if not Board members[.]"53 In addition, the majority highlighted Sarbanes-Oxley's provision empowering the SEC to "promulgate such rules and regulations, as may be necessary or appropriate in the public interest, or for the protection of investors, in furtherance of this Act." 54

The majority's view of the PCAOB as a "heavily controlled component" of the SEC was essential to its ultimate conclusion that the PCAOB's structure violates neither the Appointments Clause nor the doctrine of separation of powers. With respect to the Appointments Clause, the majority held that "in view of the Commission's comprehensive control of the Board, Board members are subject to direction and supervision of the Commission and thus

45. Id. at 673 .

46. Id. at 698 (Kavanaugh, J., dissenting).

47. Id. at 669 .

48. Id. at 672 (citing 15 U.S.C. $\S 7217(\mathrm{~b})(5)(2006)$ ).

49. Id. (quoting 15 U.S.C. $\$ 7217(\mathrm{c})(3))$.

50. Id. at 680 .

51. Id. at 669 (citing 15 U.S. C. $\$ 7219$ (c), (d) (2006)).

52. Id. at 680 .

53. Id. at 683 .

54. 15 U.S.C. $\S 7202$ (a) (2006) (as cited in Free Enterprise Fund, 537 F.3d at 673). 
are inferior officers not required to be appointed by the President." 55 With respect to the separation of powers claim, the majority held that the statutory limitations on the SEC's power to remove PCAOB members coupled with the for-cause limitations on the President's power to remove the SEC's Commissioners "do not strip the President of sufficient power to influence the Board and thus do not contravene separation of powers, as that principle embraces independent agencies like the Commission and their exercise of broad authority over their subordinates." 56

Judge Kavanaugh's view that the PCAOB constitutes an "independent agency," notwithstanding the SEC's oversight and enforcement authority over the Board, was likewise essential to his conclusion that the PCAOB's structure violates both the Appointments Clause and principles of separation of power. In his view, PCAOB members are not "inferior officers" within the meaning of the Appointments Clause because they "are not 'directed and supervised' by the SEC." ${ }^{\text {57 }}$ Here, Judge Kavanaugh emphasized that the SEC lacks at-will removal authority over Board members, "the SEC does not have statutory authority to remove them for failure to follow substantive SEC direction or supervision; and the SEC does not have statutory authority to prevent and affirmatively command, and to manage the ongoing conduct of, Board inspections, Board investigations, and Board enforcement actions." Thus, as Judge Kavanaugh saw it, the PCAOB's five members are "principal officers" who must be appointed by the President subject to advice and consent from the Senate. He also emphasized that the PCAOB's five members are removable for cause only by the SEC, which is itself an independent agency whose members are removable only for cause by the President, and that the "President's power to remove is critical to the President's power to control the Executive Branch and perform his Article II responsibilities." 59 Accordingly, Judge Kavanaugh concluded that the PCAOB's structure violates separation of powers because the President's "two levels of for-cause removal away from Board members ... effectively eliminates any Presidential power to control the PCAOB, notwithstanding that the Board performs

55. Free Enterprise Fund, 537 F.3d at 669 (referencing the "direction and supervision" test that the Supreme Court articulated in Edmond v. United States, 520 U.S. 651, 663 (1997)).

56. Id.

57. Id. at 687 (Kavanaugh, J., dissenting) (quoting Edmond, 520 U.S. at 663).

58. Id. at 687 (Kavanaugh, J., dissenting).

59. Id. at 686 (Kavanaugh, J., dissenting). 
numerous regulatory and law-enforcement functions at the core of executive power." 60

\section{Part Two: The PCAOB's Substantive Independence From the SEC}

As the above snapshot reveals, the three members of the D.C. Circuit panel differed not so much in their view of the Constitution as in their view of the structural relationship between the SEC and the PCAOB. The majority went so far as to observe that if "the Board is itself an independent agency ... the dissent's conclusion that the Board's structure is unconstitutional conveniently follows."

The analysis in this Part explains why the panel majority's depiction of the PCAOB as a "heavily controlled component" of the SEC is inaccurate. Section A examines Sarbanes-Oxley's establishment of the PCAOB as a private corporation and takes issue with the view that the PCAOB is a "component" of the SEC. Section B then highlights the statutory text and legislative history evidencing Congress's intent to establish the PCAOB as a strong, independent board headed by five members who would act with substantial discretion and autonomy. Section C examines the SRO model on which the PCAOB was patterned. This model, and the SEC's own statements regarding SRO discretion and autonomy, bolsters the conclusion that Congress designed the PCAOB to be substantively independent from the SEC. The fourth and final section examines the constitutional doctrine of nondelegation and explains why this doctrine provides valuable insight into congressional decisions regarding the PCAOB's design. This examination, in turn, informs the analysis of the Appointments Clause and separation of powers issues in the final Part of this Article.

\section{A. The PCAOB's Status as a Corporation in the Private Sector}

Congress's decision to create the PCAOB as a nonprofit corporation in the private sector belies the characterization of the PCAOB as a "component" of the SEC, or as a "regulatory subunit" within the SEC, as amici supporting the PCAOB have suggested. ${ }^{62}$ As the Supreme Court explained in Lebron,

60. Id.

61. Free Enterprise Fund, 537 F.3d at 680 n.9.

62. See Brief of Amici Curiae Former Chairmen of the Sec. and Exch. Comm'n, Free Enterprise Fund v. Public Co. Account. Over. Bd., 537 F.3d 667 (D.C. Cir. 2008), at 10. See also id. at 2 (arguing that "[b]ecause Congress has the power to create independent agencies, it has the lesser power of creating 
although Congress's decision to situate an entity in the private sector is not determinative of its status for constitutional purposes, Congress's choice of the private sector "is assuredly dispositive of" that entity's status "for purposes of matters that are within Congress's control-for example, whether it is subject to statutes that impose obligations or confer powers upon Government entities, such as the Administrative Procedure Act, the Federal Advisory Committee Act, and the laws governing Government procurement." ${ }^{63}$ Congress's decision to situate the PCAOB in the private sector should also be dispositive as to whether the PCAOB is a "component" or a "regulatory subunit" of the SEC.

By establishing the PCAOB as a private corporation, Congress ensured that the PCAOB would stand separate and apart from the SEC. It is that separateness that exempts the PCAOB from statutes applicable to federal "agencies," including those statutes cited by the Court in Lebron. The PCAOB's separateness from the SEC also facilitates the substantial salaries that are paid to PCAOB members and employees. In 2008, the Chairman of the PCAOB received a salary of $\$ 654,406$, and the PCAOB's four other members received $\$ 531,995 .^{64}$ Those salaries are almost four times the amount received by the SEC's Chairman and Commissioners, but are comparable to those commanded in the private sector. Congress's concern about salary competiveness is clear from the Act's text, which authorizes the PCAOB to fix employee salaries "at a level comparable to private sector self-regulatory, accounting, supervisory, or other staff or management positions." ${ }^{15}$ Concern about competitive compensation was no doubt an important factor in Congress's decision to situate the $\mathrm{PCAOB}$ in the private sector. ${ }^{66}$

subunits such as the PCAOB within these agencies ....").

63. Lebron, 513 U.S. at 392 (statutory citations omitted).

64. Kenneth Starr \& Viet Dinh, Op-Ed, The PCAOB: An Obstacle to President Obama's Success, WALl St. J., May 13, 2009.

65. 15 U.S.C. $\$ 7211(f)(4)(2006)$.

66. When the PCAOB's then-Chairman was asked to comment on the reasons behind Congress's choice to organize the $\mathrm{PCAOB}$ as a nonprofit corporation, he offered the following explanation:

We were created as a not-for profit corporation largely so the PCAOB could pay better than the government. . . [Members of Congress] realized that they were piling an immense responsibility on a startup, and so one of the things they figured out is you're going to have to pay people better than the government can pay.

William J. McDonough, The Fourth Annual A.A. Sommer, Jr. Lecture on Corporate, Securities \& Financial Law, 9 FordhaM J. CoRP. \& Fin. L. 583, 599 (2004). PCAOB board member Charles Niemeier shared a similar opinion:

Congress had a stroke of genius when it chose to organize the board as an independent not-forprofit organization rather than as a unit of the government. The board will be able to offer a compensation structure that will attract highly qualified individuals and offer them a career path 
Attempts to salvage the $\mathrm{PCAOB}$ 's constitutionality by reconstructing it as a "component" or a "regulatory subunit" of the SEC are particularly inappropriate because Congress specifically considered that alternative and rejected it in favor of the structure ultimately selected for the PCAOB. In creating the $\mathrm{PCAOB}$ as an independent regulator in the private sector, Congress acted contrary to the advice provided by its own agent, the Comptroller General of the United States.

In the Senate hearings that preceded the enactment of Sarbanes-Oxley, then-Comptroller General David Walker testified that there were "several alternative structures" from which Congress could choose in establishing a new regulator for the accounting industry, including the creation of: "(1) a new unit within the SEC; (2) an independent government entity within the SEC; (3) an independent government agency outside the SEC; or (4) a nongovernmental private-sector body overseen by the SEC."67 Although he recognized that all four alternatives had strengths and weaknesses, the Comptroller General believed that alternatives one and four had lesser likelihoods of success. He specifically noted that "under alternatives one and four, the new body would have less direct accountability to the Congress and the public than a body with board members who are PASs [President appointed confirmed by the Senate]." 68

The legislative history further reveals that the House of Representatives had initially favored an alternative altogether different from the four suggested by the Comptroller General. Under the proposed "Corporate and Auditing Accountability, Responsibility, and Transparency Act" (CAARTA), a bill sponsored by Representative Michael Oxley, Congress would have established explicit criteria for "public regulatory organizations," but Congress itself would not have created any such entity. ${ }^{69}$ Rather, the bill required the SEC to promulgate rules reflecting and supplementing the congressional criteria, and authorized the SEC to "recognize" entities that applied to the SEC pursuant to its rules. ${ }^{70}$ As such, this section of the CAARTA bore a close resemblance

that simply is not possible for people in the government.

Robert H. Colson, Maintaining Public Credibility: An Interview with Charles D. Niemeier, CPA J., Apr. 1, 2003, at 18, 19-20 (emphasis added).

67. See Oversight Hearings on Accounting Reform and Investor Protection Issues Raised by Enron and Other Public Companies Before the S. Banking, Housing, and Urban Affairs Comm., 107th Cong. 661 (2002) (Letter from David Walker, U.S. Comptroller Gen., to Sen. Paul Sarbanes) [hereinafter Oversight Hearings].

68. Id.

69. H.R. 3763, 107th Cong. § 2(b) (2002).

70. Id. §2(a). 
to provisions in the Maloney Act of $1938,{ }^{71}$ which authorized the SEC to "recognize" national securities associations, such as the NASD. Critics of the CAARTA contended that its framework left too much discretion with the SEC and the accounting industry itself, "effectively allowing these issues to remain open to debate even after Congress has acted." accounting industry's largely unsuccessful history of self-regulation. ${ }^{73}$ Although CAARTA passed the House by a vote of 334 to $90,{ }^{74}$ its "public regulatory organization" alternative was subsequently abandoned in favor of an accounting oversight board that was congressionally created.

Congress also contemplated alternatives that would have made the SEC directly responsible for the oversight of public accounting firms. A number of witnesses, including former SEC Chairman Richard Breeden, advised against the creation of a new accounting regulator, and instead urged Congress to increase the SEC's funding so that the SEC could serve as the "primary enforcer of the law." ${ }^{75}$ Responsive to these and other suggestions for enhanced SEC responsibility, H.R. 5184 would have required the SEC to "establish the Office of Audit Review within the Division of Corporate Finance of the Commission to oversee the audits of certain public companies." ${ }^{.76}$ This new

71. Pub. L. No. 75-719, 52 Stat. 1070 (1938) (codified as amended at 15 U.S.C. $\$ 780-3$ ).

72. See H.R. REP. No. 107-414, at 47-48 (2002) (presenting minority views). In the minority's view, "[d]elegating decisions on its duties and powers to the SEC provide[s] an opportunity for the new regulator to be weakened." Id.

73. See id. at 48 (referencing the "tangled jumble of existing industry organizations"). See also Nagy, supra note 6, at 996-98 (discussing the congressional hearings that led up to the passage of Sarbanes-Oxley, and noting that most witnesses "shared the view that the accounting profession's system of self-regulation was in need of a serious overhaul" and that any newly-created entity "should not be dependent for funding on the accounting profession").

74. 148 CONG. REC. 5548 (2002).

75. See Oversight Hearings, supra note 67, at 37 (testimony of Richard C. Breeden, former Chairman of the SEC) ("We don't need to go and invent another [body]. We need to invigorate the SEC and make sure it has the tools to do the job. Let's not reinvent the wheel. Downstream from the SEC, private sectors groups can be helpful .... But let's [not] lose sight. The primary enforcer of the law needs to be the Commission."). See also id. at 208 (testimony of Walter P. Schuetze, Chief Accountant, SEC, 1992-95) ("[G]ive the SEC pay parity, increase their budgets, so they can do more and better jobs. But don't create another body that is going to compete with us"); id. at 874 (prepared statement of Robert E. Litan, Director, Economic Studies Program, The Brookings Institution Bear, Stearns \& Co., Inc.) ("I urge [Congress] at least to consider whether the SEC itself should be performing the oversight of auditors directly....").

76. See The Corporate Auditing Integrity Act, H.R. $5184 \S 2,107$ th Cong. (2002) (introduced by Representative Danny Davis D-IL). 
unit within the SEC would have been self-funded through fees assessed on public companies. ${ }^{77}$ H.R. 5184, however, received little legislative support. ${ }^{78}$

Sarbanes-Oxley's text leaves no doubt that Congress ultimately chose the fourth alternative outlined in the Comptroller General's Senate testimony-the creation of "a nongovernmental private-sector entity overseen by the SEC." Thus, in depicting the PCAOB as a mere "component" of the SEC to salvage its constitutionality, the D.C. Circuit essentially turned back the clock and selected for Congress the Comptroller General's first alternative that Congress had rejected-"a unit within the SEC." Because the choice of a constitutional structure for the $\mathrm{PCAOB}$ is one that belongs to Congress, the Supreme Court should not affirm that revisionism.

\section{B. The PCAOB's Substantial Discretion and Autonomy}

The D.C. Circuit erred not only in its finding that the PCAOB was a "component" of the SEC; it was also incorrect in its assessment that SarbanesOxley's provision for SEC oversight and enforcement constitutes "extraordinary" authority, ${ }^{79}$ with the PCAOB's powers subject to "a vast degree of Commission control at every significant step." ${ }^{80}$ Both the Act's text and legislative history confirm Congress's deliberate intention to structure the PCAOB as an entity that would operate with a substantial degree of discretion and autonomy, free from SEC control in a number of important respects.

\section{The Statutory Text}

Several aspects of the statutory text evidence the PCAOB's substantive independence from the SEC. First and foremost are the Act's provisions for appointment and removal of the PCAOB's five members. PCAOB members are appointed by the SEC for staggered five-year terms, ${ }^{81}$ and are removable

77. Id. at $\$ 4$.

78. The House of Representatives also considered and rejected an alternative bill, H.R. 3795, that would have established within the SEC a "Federal Bureau of Audits" (the FBA). See Investor, Shareholder, and Employee Protection Act, H.R. 3795, 107th Cong. § 3(a) (2002) (introduced by Representative Dennis Kucinich (D., OH)). The FBA would have consisted of a Director, Deputy Director, and Inspector General and would have had the authority to "hold hearings, sign and issue subpoenas, administer oaths, examine witnesses, and receive evidence at any place in the United States it may designate." H.R. $3795 \S 3(\mathrm{~g})$.

79. Free Enterprise Fund, 537 F.3d at 669.

80. Id. at 683 .

81. 15 U.S.C. $\$ 7211(\mathrm{e})(4)(2006)$. 
by the SEC only for "good cause shown." 82 These fixed terms of service and express statutory limitations on removal ensure that $\mathrm{PCAOB}$ members are not, in the words of the D.C. Circuit, "entirely subordinate to the Commission." 83 Indeed, fixed statutory terms of service, with explicit or implicit restrictions on an official's removal, constitute the traditional hallmarks of an "independent" regulatory agency. ${ }^{84}$

PCAOB members are insulated from removal - or threats of removal - to an extent even greater than the political insulation accorded to SEC Commissioners. SEC Commissioners, like the heads of many other independent agencies, serve for fixed five-year terms. And SEC Commissioners, like other agency heads, may be removed from office only "for cause" by the President. But "cause," for purposes of Presidential removal, is typically viewed as "inefficiency, neglect of duty or malfeasance in office." ${ }^{\text {"As }}$ A contemplated removal of a PCAOB member by the SEC, in contrast, triggers specific procedural protections and requires a higher showing of culpability. The Act provides that PCAOB members may be removed only if:

The Commission finds, on the record, after notice and opportunity for a hearing, that such member:

(A) has willfully violated any provision of this Act, the rules of the Board, or the securities laws;

(B) has willfully abused the authority of that member;

or (C) without reasonable justification or excuse, has failed to enforce compliance with any such provision or rule, or any professional standard by an registered public accounting firm or any associated person thereof. ${ }^{86}$

The statutory requirement for an on-the-record finding of a Board member's "willful" violation or abuse of authority, and the specific allowance for enforcement failures based on "reasonable" justifications or excuses, constitute severe limitations on the SEC's ability to influence the five

82. 15 U.S.C. $\$ 7211(\mathrm{e})(6)$.

83. Free Enterprise Fund, 537 F.3d at 680 n.9.

84. See id. at 701 (Kavanaugh, J., dissenting) (emphasizing that the term "“independent agency' ... traditionally has been applied by the Supreme Court, the Congress, and the Executive Branch to agencies like the PCAOB whose heads are not removable at will").

85. See MFS Sec. Corp. v. SEC, 380 F.3d 611, 619 (2d Cir. 2004) (quoting SEC v. Blinder Robinson \& Co., 855 F.2d 677,681 (10th Cir. 1988) (citation and internal quotation marks omitted), cert. denied, 489 U.S. 1033 (1989)).

86. 15 U.S.C. $\$ 7217$ (d)(3) (2006). 
members of the SEC and ensure that the SEC cannot exert a "vast degree of ... control at every significant step." ${ }^{27}$

Sarbanes-Oxley's provision for fixed terms and restricted removal allow PCAOB members to remain free to establish and pursue their own policy goals and priorities, particularly with respect to PCAOB investigations, enforcement actions, and rulemaking. The SEC might, for example, conclude that the $\mathrm{PCAOB}$ is devoting too many-or too few-of its investigatory resources to the large accounting firms; or that the PCAOB is bringing too many —or too few-enforcement actions in the area of auditor independence. Likewise, the SEC could conclude that the PCAOB's rulemaking initiatives should be focusing less - or more - on the area of internal controls. The SEC, however, cannot act on its displeasure by threatening to replace one or more of the PCAOB's five members with new members whose policy priorities would be more in line with the SEC's. Once a PCAOB member is appointed, the Act effectively provides that he or she has five years to shape and pursue policy, provided that the member does not engage in willful or unjustifiable transgressions. Other than insulation from control by the SEC (and indirectly from the President and Congress), what other purpose is served by the Act's provision for fixed terms and highly circumscribed removal?

The PCAOB's substantial discretion and autonomy is further evidenced by the limited statutory role assigned to the SEC with respect to Board inspections, investigations, and enforcement determinations. To be sure, Sarbanes-Oxley provides for SEC oversight in connection with the PCAOB's final rules and disciplinary sanctions, ${ }^{88}$ and authorizes the SEC to inspect and examine the PCAOB's records. ${ }^{89}$ The Act also obligates the PCAOB to notify the SEC about any pending investigations involving potential violations of the federal securities laws, so that the PCAOB and the SEC's Division of Enforcement may coordinate their work. ${ }^{90}$ Yet the Act does not require SEC notification when an investigation relates to possible violations of the PCAOB's own rules or professional standards. Nor does the Act provide a

87. Free Enterprise Fund, 537 F.3d at 683.

88. 15 U.S.C. $\$ 7217$ (b) (2006) (providing for SEC oversight in connection with "Rules of the Board"); $§ 7217$ (c) (providing for SEC "review of disciplinary action taken by the Board"). See also supra text accompanying notes 48-52 (D.C. Circuit's discussion of the statutory text pertaining to SEC oversight).

89. 15 U.S.C. $\$ 7217$ (a) (incorporating Sections 17 (a)(1) and (b)(1) of the Exchange Act, 15 U.S.C. $\S \S 78 q(a)(1)$ and $(b)(1)(2006)$, relating to SRO records, and specifying that these provisions "shall apply to the Board as fully as if the Board were a 'registered securities association"").

90. 15 U.S.C. $\$ 7215(\mathrm{~b})(4)(\mathrm{A})(2006)$. 
role for the SEC in all of the interim steps leading up to SEC review of the PCAOB's final disciplinary sanctions.

Sarbanes-Oxley accords the PCAOB a vast array of investigative, prosecutorial, and adjudicative powers, and the Board's exercise of these powers often results in decisions that are not "subject to check by the Commission at every significant step."91 With respect to PCAOB investigations, their scope and duration (including which accounting firms and officials are investigated, and for what) rests entirely with the Board. Moreover, the Act provides that as a condition of registration, accounting firms and associated persons must consent to cooperate with the PCAOB, including any requests for the production of documents or testimony ${ }^{92}$ The Act's requirement of mandatory cooperation by registered firms and officials, enforceable through Board-imposed sanctions, ${ }^{93}$ facilitates the PCAOB's ability to uncover evidence of possible violations of professional standards, PCAOB rules, and the federal securities laws (including failures to supervise the conduct of others), and ensures that the PCAOB can obtain evidence without having to apply to the SEC for a subpoena. ${ }^{94}$

Based on the investigatory record presented by the PCAOB staff (a record that may take a year or more to compile), the Board acting in its prosecutorial capacity then decides whether enforcement action against a firm or its officials is warranted. ${ }^{95}$ That is, the Board decides who does-or does not-have to defend against specific charges, and the Board decides what those charges shall be. If the Board, acting in its prosecutorial capacity, determines that the investigatory record does not warrant enforcement action, the SEC has no statutory review role at all.

The Board's adjudicative function commences once disciplinary charges are filed against a firm or associated person. In its adjudicative capacity, the Board decides whether the facts (agreed to in a settlement or placed in

91. Free Enterprise Fund, 537 F.3d at 673.

92. 15 U.S.C. $\S 7212($ b)(3) (2006).

93. 15 U.S.C. $\$ 7215($ b)(3) (authorizing PCAOB-imposed sanctions (including suspension, bars, and revocation of registration) in the event a firm or associated person "refuses to testify, produce documents or otherwise cooperate with a PCAOB investigation").

94. To further enhance the PCAOB's powers as a regulator, the Act provides that the PCAOB may seek issuance by the SEC of a subpoena for documents or testimony, where third parties outside the auditing industry are unable or unwilling to cooperate voluntarily. 15 U.S.C. $\S 7215(\mathrm{~b})(2)(\mathrm{C})$.

95. 15 U.S.C. $\$ 7215$ (c)(1)(A)-(B) (specifying that in connection with any disciplinary proceeding, the Board shall "bring specific charges with respect to the firm or associated person," provide notice of, and "an opportunity to defend against, such charges"). 
evidence at a hearing) establish the alleged violations, ${ }^{96}$ and the Board determines the appropriate sanction if violations are found. ${ }^{97}$ Evidentiary hearings are generally conducted in the first instance by a hearing officer, though the Board retains de novo power of review. If the PCAOB imposes a disciplinary sanction, the Board must report that sanction to the SEC, applicable state or foreign licensing boards, and the public (once any stay on the imposition of such sanction has been lifted). ${ }^{98}$ Sanctions available include censures, temporary suspensions or permanent revocations of registration, temporary suspensions or permanent bars from a person's further association with a registered accounting firm, and civil monetary penalties up to $\$ 750,000$ for natural persons and $\$ 15,000,000$ for any other person (for each violation). ${ }^{99}$ The Act provides that disciplinary sanctions are automatically stayed upon application to the SEC for review, or the institution by the SEC of review. ${ }^{100}$

Accordingly, the SEC's review role in connection with PCAOB disciplinary proceedings is an adjudicatory one. Congress accorded the SEC de novo review power over Board discipline, and provided that the SEC "may enhance, modify, cancel, reduce or require the remission of a sanction imposed by the Board."101 The SEC's final order affirming or modifying a PCAOB decision is itself subject to review by a federal circuit court. ${ }^{102}$ But the SEC and federal courts provide a check on the PCAOB only if the Board orders a disciplinary sanction. If the Board determines that the alleged charges are not supported by the evidence presented at a hearing, that decision is not subject to review by the SEC.

The D.C. Circuit did not dispute Sarbanes-Oxley's failure to assign the SEC any specific role in PCAOB inspections, investigations, and enforcement determinations (beyond the SEC's general rulemaking power "in furtherance" of the $\mathrm{Act}^{103}$ and its statutory responsibility to review and approve all PCAOB rules, including rules governing the conduct investigations and disciplinary

96. 15 U.S.C. $\S 7215(c)(3)$.

97. 15 U.S.C. $\S 7215(c)(4)$.

98. 15 U.S.C. $\S 7215(d)(1)$.

99. 15 U.S.C. $87215(c)(4)$.

100. 15 U.S.C. $\$ 7215(\mathrm{e})$.

101. 15 U.S.C. $\$ 7217(\mathrm{c})(2)-(3)(2006)$

102. 15 U.S.C. $\S 78 y(a)$ (2006) (providing that a "person aggrieved by a final order of the Commission entered pursuant to this title may obtain review of the order in the United States Court of Appeals for the circuit in which he resides or has his principal place of business, or for the District of Columbia").

103. See supra note 54 and accompanying text. 
proceedings). ${ }^{104}$ But the court nonetheless regarded the PCAOB's autonomy in these areas as trumped by the statute's "sweeping" provisions for SEC limitations and restrictions on Board authority. ${ }^{105}$ Specifically, the Act provides that: "The Commission by rule, consistent with the public interest, ... may relieve the Board of any responsibility to enforce compliance with any provision of this Act, the federal securities laws, the rules of the Board, or professional standards." ${ }^{106}$ In addition, the Act provides that:

The Commission may, by order, as it determines necessary or appropriate in the public interest ... censure or impose limitations upon the activities, functions, and operations of the Board if the Commission finds, on the record, after notice and opportunity for a hearing, that the Board-

(A) has violated or is unable to comply with any provision of this Act, the rules of the Board, or the securities laws; or

(B) without reasonable justification or excuse, has failed to enforce compliance with any such provision or rule, or any professional standard by a registered public accounting firm or an associated person thereof. ${ }^{107}$

Thus, in the view of the D.C. Circuit, Congress essentially granted the SEC "at-will removal power over Board functions if not Board members[.]"108

But unlike Sarbanes-Oxley's oversight provisions, which obligate the SEC to review the PCAOB's final rules and disciplinary actions, the SEC's enforcement authority over the PCAOB, including its authority to displace or limit Board functions, is merely an SEC power to sanction the PCAOB for transgressions. In fact, the very caption of that subsection of the Act terms this authority a "sanction." 109 The majority's supposition that the SEC may limit or remove "Board authority altogether" is therefore subject to an essential statutory prerequisite: The SEC must issue an order after an on-the-record finding that the $\mathrm{PCAOB}$ engaged in sanctionable misconduct. Moreover, while the SEC may promulgate a rule "reliev[ing]" the Board of any of its enforcement responsibilities, the APA requires the SEC to provide a reasoned explanation of its action after notice and the opportunity for public

104. See supra notes $48-50$ and accompanying text.

105. Free Enterprise Fund, 537 F.3d at 680 .

106. 15 U.S.C. $\$ 7217(\mathrm{~d})(1)$.

107. 15 U.S.C. $\S 7217$ (d)(2)(B).

108. Free Enterprise Fund, 537 F.3d at 683.

109. 15 U.S.C. $\$ 7217$ (d) (captioned "Censure of the Board; Other Sanctions"). 
comment, ${ }^{110}$ and the rule itself would be subject to review by a federal court. ${ }^{11}$

There are also many provisions in the Act that would be superfluous if the PCAOB were, as the D.C. Circuit found, subject to the SEC's "extraordinary" direction and supervision. For example, the PCAOB is authorized to refer an investigation to the SEC, ${ }^{112}$ and is permitted to share with the SEC the otherwise confidential documents and materials received by the Board in the course of its inspections and investigations. ${ }^{113}$ These provisions authorizing referrals and permitting disclosure of investigative materials would have been unnecessary had Congress truly intended the members of the PCAOB to operate as "subordinates" of the SEC's Commissioners.

Likewise, if Congress had intended the members of the PCAOB to function as the subordinates of the SEC, it almost certainly would have assigned the SEC additional responsibilities to facilitate the SEC's purported direction and supervision of Board members and employees. Instead, Congress concentrated the SEC's oversight in three principal areas: rulemaking, disciplinary proceedings, and funding. With respect to this latter responsibility, the SEC must approve the PCAOB's annual budget, ${ }^{114}$ and must approve the formula for calculating the "accounting support fee" that Congress authorized the PCAOB to impose on all public companies to fund Board operations. ${ }^{15}$

The statutory design thus ensures that no PCAOB rule can become law, no PCAOB sanction can be imposed on a firm or accountant, and no PCAOBimposed tax can be levied on a public company, over the SEC's specific objection. As we shall see, insofar as the PCAOB is a private-sector corporation, government oversight in connection with its rulemaking, disciplinary proceedings, and taxing authority is essential. ${ }^{16}$ Sarbanes-Oxley's provisions for SEC oversight of the PCAOB, with very few exceptions, reflect

110. See 5 U.S.C. $\S 553$ (2006); Motor Vehicle Mfrs. Ass'n v. State Farm Mut. Auto. Ins. Co., 463 U.S. 29 (1983).

111. See 5 U.S.C. $\$ 702$ (2006) (“A person ... adversely affected or aggrieved by agency action within the meaning of a relevant statute, is entitled to judicial review thereof.").

112. 15 U.S.C. $\$ 7215(\mathrm{~b})(4)(B)(2006)$.

113. 15 U.S.C. $\$ 7215(\mathrm{~b})(5)(\mathrm{B})$.

114. 15 U.S.C. $\$ 7219(\mathrm{~b})(2006)$.

115. 15 U.S.C. $\$ 7219$ (d) ("[T] Be Board shall establish, with the approval of the Commission, a reasonable annual accounting support fee (or a formula for the computation thereof), as may be necessary or appropriate to establish and maintain the Board.").

116. See infra Part II.D (discussing the constitutional doctrine of nondelegation). 
a constitutional rock-bottom minimum for a valid congressional delegation of governmental power to a "private" corporation."

\section{Legislative History}

The legislative history of Sarbanes-Oxley reinforces the text's design of a board that is substantively independent, not only from the accounting industry that it regulates, but also from the SEC and elected officials to whom the SEC is answerable. The Senate Report explains that the Act "creates a strong, independent board to oversee the conduct of the auditors of public companies"118 and emphasizes the Board's "plenary" rulemaking, ${ }^{119}$ and its "broad authority to investigate" possible violations of PCAOB rules, the Act, or the federal securities laws. ${ }^{120}$ The congressional record is also replete with references to the PCAOB as a "strong, independent ... board with significant authority," $" 21$ and with respect to $\mathrm{PCAOB}$ rulemaking, states specifically that "[t]he board would possess plenary authority to establish or adopt auditing, quality control, ethics, and independence standards for the auditing of public companies." 122 The record further reflects at least one Senator's view of the Board as an entity with "massive power, unchecked power, by design."123

Senator Phil Gramm's reference to the PCAOB's "massive power, unchecked power" merits more than a mere snippet. Less than three weeks before the passage of the Act, Senator Gramm shared with his colleagues the view that:

117. The D.C. Circuit twice noted that the PCAOB's power to "sue and be sued, complain and defend" is subject to the SEC's approval. Free Enterprise Fund, 537 F.3d at 670, 681 (citing 15 U.S.C. $\S 7211(f)(1)(2006)$ ). Congress may have included this provision to effectively preclude the PCAOB, as a corporate entity in its own right, from instituting litigation against the SEC. The possibility of a regulator subject to SEC oversight initiating litigation against its "overseer" was not unprecedented. See Nat'l Ass'n of Sec. Dealers v. SEC, 431 F.3d 803 (D.C. Cir. 2005) (dismissing the NASD's petition for review of an SEC order and concluding that the NASD is not a "person aggrieved" under Exchange Act $\S 25$ (a) when the SEC exercises its statutory power of de novo review to reverse an NASD disciplinary proceeding).

118. S. REP. No. 107-205, at 2 (2002).

119. Id, at 8 .

120. Id. at 10 .

121. See, e.g., 148 Cong. REc. 12,955 (2002) (statement of Sen. Dodd); id. at 21,116 (statement of Sen. Sarbanes) (stating that the PCAOB was established by "statute in order to provide an extra guarantee of its independence and its plenary authority to deal with this important situation"). See also S. REP. No. 107-205, at 6 (2002) ("The successful operation of the Board depends upon its independence ....").

122. 148 CONG. REC. 12,115 (2002) (statement of Sen. Sarbanes).

123. 148 CONG. REC. 12,119 (2002) (statement of Sen. Gramm). 


\begin{abstract}
Anybody who thinks this board is just going to slap around a few accountants does not understand this bill. This board is going to have massive power, unchecked power, by design. I would have to say the board that Senator Enzi and I set up in our bill has massive unchecked power as well. I mean, that is the nature of what we are trying to do here. I am not criticizing Senator Sarbanes. I am just reminding people that there are two edges of this sword. We are setting up a board with massive power that is going to make decisions that affect all accountants and everybody they work for, which directly or indirectly is every breathing person in the country. They are going to have massive unchecked powers. ${ }^{124}$
\end{abstract}

When placed in full context, Senator Gramm's references to the PCAOB's "massive unchecked powers" can hardly be dismissed, as the PCAOB has urged, as a view from a "legislative opponent[ ]." ${ }^{25}$ In fact, as Senator Gramm candidly acknowledged, he initially opposed establishing the PCAOB because he favored an alternative structure, proposed by Senator Enzi and himself, that would have made the board "a little more independent of the SEC" by providing for presidential appointment of the board's chairman and direct appeals of board rulemaking and disciplinary sanctions to a federal district court. ${ }^{126}$ Senator Gramm's statements provide powerful evidence that Congress sought to create a PCAOB that was independent of the SEC to a significant degree. And the fact that the Senator initially sought to persuade his colleagues to support a board that was designed to be " $a$ little more independent of the SEC" should only bolster the accuracy of his assessment of the Board for which he ultimately voted.

The legislative record also facilitates our understanding of why Congress was particularly concerned about the PCAOB's ability to exercise independent judgment in connection with auditor oversight: As the D.C. Circuit recognized and acknowledged, "the level of Presidential control over the Board reflects Congress's intention to insulate the Board from partisan forces." 127 In particular, Congress sought to avert the "extraordinary amount of political pressure" previously directed at the SEC's Commissioners, when the SEC had attempted during the 2000 election year to promulgate stricter requirements for auditor independence. ${ }^{128}$ As Senator Paul Sarbanes recounted during a

124. Id.

125. Brief for Respondents Public Company Accounting Oversight Board et al., at 29, Free Enterprise Fund v. Public Co. Account. Over. Bd., No. 08-861 (Oct. 13, 2009) (stating that the "views of legislative opponents are hardly authoritative" and describing Senator Gramm as "the bill's 'main critic' who 'decided at the last minute to vote for it"') (quoting Cornwell, U.S. Congress Sends Corporate Reform Bill to Bush, REUTERS NEWS, July 26, 2002).

126. See 148 Cong. REC. $12,120,12,122$ (2002) (statements of Sen. Gramm).

127. Free Enterprise Fund, 537 F.3d at 682.

128. Oversight Hearings, supra note 67, at 15 (statement by Arthur Levitt, former Chairman of the 
hearing, several witnesses had advised Congress that "if we can structure the board well enough, it might actually have more independence from political influence than the SEC would have." 129 And Senator Debbie Stabenow raised her own concern "about finding a better way to insulate the establishment of accounting standards from politics and pressure, both from the industry, and frankly, from Congress." 130

Congress's intention to insulate the $\mathrm{PCAOB}$ from political influence and partisan forces would be thwarted if the PCAOB could, in the words of the D.C. Circuit, be "micromanag[ed]" by the SEC. ${ }^{131}$ Recognizing that the past is prologue, Congress feared that its own members and the President might be tempted to persuade the SEC to adopt positions favored by their powerful constituents and contributors. Congress also may have surmised that the SEC, headed by a Chairman who serves at the pleasure of the President, and composed (at the time) of a majority of members from the President's political party, would be more inclined to favor the President's policy preferences. ${ }^{132}$ Accordingly, fueled with bipartisan spirit in the wake of the collapses of Enron and WorldCom, Congress designed the PCAOB to be doubly insulated from political and partisan pressure.

Public company accounting oversight could have been placed in a new unit within the SEC - and that new unit could have been self-funded through fees paid by public companies. ${ }^{133}$ But a new unit within the SEC (even a selffunded unit) would have been subject to the SEC's plenary control, and thus

SEC). See also ARTHUR LevitT, TAKe ON THE STREET 139-40 (2002) (stating that the "Big Five firms, their partners, and the AICPA pumped gobs of money into the election coffers of hundreds of Congressional candidates and the Bush campaign" and noting that "[e]ach of the Big Five also appears on the list of President Bush's top twenty contributors").

129. Id. at 1027 (statement by Sen. Paul Sarbanes)

130. Id. at 186 (statement by Sen. Debbie Stabenow).

131. Free Enterprise Fund, 537 F.3d at 683.

132. Cf. Neal Devins \& David E. Lewis, Not-So Independent Agencies: Party Polarization and the Limits of Institutional Design, 88 B.U. L. REV. 459, 462 (2008) (detailing empirical findings and contending that "Presidents-once there is a majority of commissioners from the President's party-have more influence on independent-agency policymaking than ever before"). At the time of Sarbanes-Oxley, the SEC was chaired by Harvey Pitt, a Republican who had been appointed by President George W. Bush. The other Commissioners were Cynthia Glassman (a Republican) and Issac Hunt (a Democrat). Two Commissioner seats were vacant. See SEC Historical Summary of Chairman and Commissioners, available at http:/www.sec.gov/about/sechistoricalsummary.htm. Democrats had a majority in the Senate; Republicans had a majority in the House of Representatives.

133. See supra notes 76-78 and accompanying text (discussing H.R. 5184, which would have required the SEC to establish a self-funded Office of Audit Review within the Division of Corporate Finance). Examples of federal entities that are self-funded include the Federal Reserve and the Federal Deposit Insurance Corporation (FDIC). See Nagy, supra note 6, at 1026-27. 
the new unit would have more susceptible to indirect control by the President and Congress. ${ }^{134}$ Although subject to SEC oversight and enforcement authority, Board members with fixed five-year terms and strict restrictions on removal were far more likely to bring their independent judgment to bear on the critical issues that faced the auditing industry in the wake of the scandals. The PCAOB's independence from the SEC was not an end in itself, but rather a means to the end of depoliticizing the PCAOB.

There is certainly an argument to be made that the PCAOB's design has furthered the congressional goal of insulating the Board from political influence and partisan forces. ${ }^{135}$ But as we shall see in Part III of this Article, the Constitution ensures that all governmental power is subject to constitutional checks and balances, and some of these checks are derived from the political process itself. The PCAOB's design may have been rooted in pragmatism, but the PCAOB's double-decker independence fatally clashes with the democratic accountability demanded by the Constitution.

\section{The SRO Model}

Congress patterned the PCAOB on the securities industry's selfregulatory model, under which SROs, such as FINRA and the NYSE, exercise substantial regulatory powers subject to SEC oversight. ${ }^{136}$ But there is a simple reason why that model has not triggered the Appointments Clause and separation of power challenges that are now being directed at the PCAOB: SROs, such as the NASD (now FINRA) and the NYSE, are not created by the government, and their officials are not appointed by the government. ${ }^{137}$ Accordingly, the NYSE and FINRA, unlike the PCAOB, are not part of the

134. See Lawrence A. Cunningham, The Sarbanes-Oxley Yawn: Heavy Rhetoric, Light Reform (And It Just Might Work), 35 ConN. L. Rev. 915, 981 (2003) (observing that Congress could have reposed all power to set accounting and auditing standards "in the SEC itself," but contending that such "sole direct power could further politicize the standard-setting process").

135. But see Fed. Commc'n Comm'n v. Fox Television Station, 129 S. Ct. 1800, 1815 (2009) (observing that "independent agencies are sheltered not from politics but from the President, ... and their freedom from presidential oversight (and protection) has simply been replaced by increased subservience to congressional direction").

136. See Free Enterprise Fund, 537 F.3d at 683 n.13 (concluding that the PCAOB is not "an unprecedented Congressional innovation" because the SEC's "wide-ranging oversight over the Board was modeled after the rules" regarding SEC authority over SROs).

137. See Nagy, supra note 6, at 1022--25 (observing that both the NYSE and the Investment Bankers Association of America (a trade group that later restructured to become the NASD) "were formed at the initiative of securities brokers and firms long before Congress enveloped them in a regulatory scheme" and emphasizing that neither the NYSE, nor FINRA, have a governmentally-appointed board). 
"government itself" under Lebron v. National R.R. Passenger Corp.,${ }^{138}$ and NYSE and FINRA officials are not federal officers or employees for purposes of the Appointments Clause. ${ }^{139}$

The SRO model is nonetheless important to our understanding of the structural relationship between the PCAOB and the SEC. Because the statutory provisions granting the SEC oversight and enforcement authority over the PCAOB are virtually identical to the statutory provisions providing for SEC oversight and enforcement authority over the NYSE and FINRA, the SEC's 70-year history with SRO rulemaking, investigations, and enforcement tells us much about the SEC's ability to "direct and supervise" or otherwise control the PCAOB.

The similarities between the PCAOB and the NYSE and FINRA are striking. As with the PCAOB, Congress has delegated substantial rulemaking, enforcement, and adjudicatory powers to these private self-regulators, with each SRO's recordkeeping, rulemaking, and disciplinary actions subject to SEC oversight. ${ }^{140}$ The SEC may also "by rule ... abrogate, add to, and delete from" the rules of an SRO. ${ }^{141}$ Moreover, as with the PCAOB, the SEC has enforcement authority over the SROs. Specifically, the SEC may, by order, suspend or revoke the registration of an SRO, or "censure or impose limitations on the activities, functions, and operations" of an SRO, upon a finding that the SRO has either violated, or is unable to comply with the law or, "without reasonable justification or excuse, has failed to enforce" any member firm's or any associated person's compliance with any such provision or rule. ${ }^{142}$ The SEC may also remove any SRO officer or director for willful violations of law or abuses of authority. ${ }^{143}$ Finally, as with the PCAOB, the SEC may, by rule, "relieve" an SRO of any of its enforcement responsibilities under the Exchange Act. ${ }^{144}$

138. Lebron, 513 U.S. at 400.

139. See Nagy, supra note 6, at 1022-25.

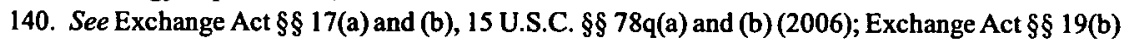
and (d), 15 U.S.C. $\S \S 78 s(b)$ and (d) (2006).

141. Exchange Act $\S 19(\mathrm{c}), 15$ U.S.C. $\$ 78 \mathrm{~s}(\mathrm{c})$.

142. Exchange Act, $\S 19(\mathrm{~h})(1), 15$ U.S.C. $\S 78 \mathrm{~s}(\mathrm{~h})(1)$.

143. Exchange Act $\S 19(\mathrm{~h})(4), 15$ U.S.C. $\S 78 \mathrm{~s}(\mathrm{~h})(4)$.

144. Exchange Act $\S 19(\mathrm{~g})(2), 15$ U.S.C. $\S 78 \mathrm{~s}(\mathrm{~g})(2)$. To the extent that there are differences between the PCAOB and the NYSE and FINRA beyond the critical distinction of the PCAOB's governmental creation and appointment of members, these differences are principally designed to make the PCAOB an even more powerful regulator than the SROs. These differences include: the PCAOB's guaranteed source of funding through statutorily mandated accounting support fees paid by public companies, 15 U.S.C. $\S 7219$ (d)(1) (2006); a means for the PCAOB to subpoena testimony and documents (from persons other than registered accounting firms and their employees) through requests to the SEC, 15 U.S.C. 
The SRO model thus provides for SEC oversight and enforcement authority over the private self-regulators in the securities industry. But the NYSE and the FINRA exercise substantial autonomy and discretion, notwithstanding the SEC's authority, and the SEC does not control these SROs at every significant step. As former SEC Chairman Justice William O. Douglas once explained, the SRO model in the securities industry lets "the exchanges take the leadership with Government playing a residual role. Government would keep the shotgun, so to speak, behind the door, loaded, well oiled, cleaned, ready for use, but with the hope it would never have to be used." 145 Although Congress revised the statutory scheme in 1975 to provide for additional SEC oversight and enforcement authority over the SROs (as reflected in the provisions discussed above), the fundamental framework recognized by Justice Douglas has remained unchanged. ${ }^{146}$

Title I of Sarbanes-Oxley reflects a similar congressional intention to assign "leadership" over the accounting industry to the PCAOB, with the SEC playing the "residual role." The statutory design ensured that the PCAOB would take leadership in the area of rulemaking - with the PCAOB's authority described as "plenary." executive functions involving inspections and investigations of, and enforcement actions against, auditors of public companies. The fact that the SEC can theoretically pick up a well-oiled "shotgun" sometime in the future does not make the SEC the superior of the PCAOB for the present while that shotgun remains behind the door.

To be sure, the Supreme Court has described the SEC's "supervisory authority" over the SROs as "extensive" and "pervasive."148 The Court, however, made those observations in the context of the SEC's statutory responsibility to review and approve proposed SRO rules. ${ }^{149}$ Because no SRO

$\S 7215$ (b)(2)(D) (2006); immunity for PCAOB officials "to the same extent as an employee of the Federal Government in similar circumstances," $\S 7215(\mathrm{~b})(6)$; and a statutory privilege from third party discovery of PCAOB materials, $\S 7215(\mathrm{~b})(5)$.

145. William O. Douglas, Democracy and Finance 82 (James Allen ed., 1940) (cited in Silver v. New York Stock Exchange, 373 U.S. 292, 352 (1963)).

146. See Fair Administration and Governance of Self-Regulatory Organizations, Exchange Act Release No. 50699, 69 Fed. Reg. 71,126, at 71,128 (Dec. 8, 2004) (stating that while "the Commission has ultimate responsibility for oversight of the U.S. securities markets and their participants, the SROs continue to have 'front-line' responsibility for overseeing trading on their markets and their members' compliance with applicable statutory and regulatory provisions").

147. See supra note 122 and accompanying text (quoting statement by Sen. Sarbanes).

148. United States v. National Association of Securities Dealers, Inc., 422 U.S. 694, 732-33 (1975).

149. See id. 
rule can become effective over the SEC's objection, ${ }^{150}$ a large part of SRO rulemaking is clearly subject to the SEC's supervision. But rulemaking agendas are generally set by the SROs-not by the SEC. The SEC suggests new initiatives, provides input and feedback, and may threaten to step in with the agency's own rules in instances of SRO inaction. Yet when it comes to their own rulemaking, SROs seldom act under the SEC's direction. ${ }^{151}$ Consequently, SRO rules are only rarely considered "state action" for purposes of constitutional protections or requirements in federal statutes. ${ }^{152}$

The SEC also performs an extensive role as reviewer of SRO disciplinary sanctions and, thus, no SRO member or associated person may be subject to discipline over the SEC's objection. ${ }^{133}$ Yet the SEC's de novo review authority over SRO sanctions does not alter the fact that SROs typically operate with substantial discretion and autonomy, free from SEC control, in all of the many steps leading up to those disciplinary sanctions. Although SROs are required under the Exchange Act "to provide a fair procedure for the disciplining of members," 154 SROs generally conduct their investigations, enforcement determinations, and adjudications free from dictates by the SEC.

Indeed, for purposes of constitutional protections such as the Fifth Amendment's privilege against self-incrimination, the SEC and courts have consistently refused to regard SRO action as "state action" precisely because SRO investigations and disciplinary proceedings are not conducted under the direction and supervision of the SEC. ${ }^{155}$ Only on those infrequent occasions

150. See supra notes $140-41$ and accompanying text (discussing Exchange Act provisions with respect to SEC review of SRO rulemaking).

151. Former SEC Chairman Arthur Levitt devotes an entire chapter of his book to the topic of securities analysts and the conflicts of interest they faced in connection with their "sell-side" research and recommendations. LEVIrT, supra note 128, at 70-92. The chapter discusses in great detail the SEC's multiyear struggle to convince the SROs to "come up with a new code of conduct for analysts." $1 d$. at 73 .

152. See, e.g., Desiderio v. Nat'l Ass'n of Sec. Dealers, 191 F.3d 198, 207 (2d Cir. 1999) (holding that the SEC's "mere approval" of a rule on an NASD form is not sufficient to constitute state action, and emphasizing that the SEC would be responsible for the NASD rule "only where it exercised coercive power or provided significant encouragement").

153. See supra note 140 and accompanying text (discussing Exchange Act provisions with respect to SEC review of SRO disciplinary sanctions).

154. Exchange Act $\S 15 A(b)(8), 15$ U.S.C. $\S 780-3(b)(8)(2006)$.

155. See, e.g., D.L. Cromwell Inv., Inc. v. NASD Regulation, Inc., 279 F.3d 155, 161 (2d Cir. 2002) (stating that the Fifth Amendment "will constrain a private entity only insofar as its actions are found to be 'fairly attributable' to the government" (citing Lugar v. Edmondson Oil Co., 457 U.S. 922,937 (1982))); United States v. Solomon, 509 F.2d 863 (2d Cir. 1975) (finding no violation of the Fifth Amendment where the government relied on testimony that was compelled in an NYSE investigation). See generally Alan Lawhead, Useful Limits to the Fifth Amendment: Examining the Benefits that Flow From A Private Regulator's Ability to Demand Answers to its Questions During an Investigation, 2009 Colum. Bus. L. REv. 1, 256-58 (citing cases and concluding that the "uniform result reached by lower federal courts and 
in which the SRO engages in "joint action" with the SEC or the DOJ, or when the government uses coercive power or "significantly encourages" SRO action, can "state action" be claimed. ${ }^{156}$

In a typical SRO investigation, however, such government coercion or joint action is not present. As one FINRA official has explained,

FINRA's investigations are not pre-cleared by the SEC. The SEC has no statutory authority, and therefore no coercive power to order FINRA to litigate any specific case. The initiative for typical cases is entirely FINRA's. FINRA investigates, files a complaint, and litigates the case, all without any government approval or pressure to do so. Because the decisions are made by FINRA, FINRA is not a state actor under the government compulsion test. ${ }^{157}$

Moreover, under "joint-action" analysis, facts demonstrating cooperation between an SRO and the SEC will rarely render an SRO a state actor, ${ }^{158}$ and "the mere fact of such collaboration is generally insufficient, standing alone, to demonstrate state action." 159

With respect to SRO disciplinary proceedings, both the SEC and federal courts have routinely depicted the SEC's role as a limited one. As the SEC has itself emphasized,

SRO proceedings are not initiated by a government agency, nor does their initiation require our approval. We do not participate in the disciplinary proceeding before the SRO, and we do not control when the SRO begins or concludes its determination. Our sole responsibility in this context arises when an SRO imposes a final disciplinary sanction on a person who seeks review of the SRO's determination from this Commission. ${ }^{160}$

the SEC has been that FINRA, NASD, and the New York Stock Exchange are private actors"). But see Roberta S. Karmel, Should Securities Industry Self-Regulatory Organizations Be Considered Government Agencies?, 14 STAN. J.L. BuS. \& FiN. 151, 171-78 (2008) (observing that judicial decisions regarding SRO immunity are very difficult to reconcile with constitutional decisions concluding that SROs are not state actors).

156. Lawhead, supra note 155, at 248-56 (discussing "government compulsion" and "joint action" tests for state action); Karmel, supra note 155, at 177-81.

157. See Lawhead, supra note 155 , at 250.

158. See D.L. Cromwell Inv., 279 F.3d at 161.

159. See, e.g., In re Frank Quattrone, Release No. 53547, 87 S.E.C. Docket 1847, 1851-52 (Mar. 24 , 2006) (emphasizing that "cooperation between the Commission and the NASD will rarely render NASD a state actor," but holding that respondent "proffered enough evidence concerning the Joint Investigation to earn an evidentiary hearing").

160. In re Larry Ira Klein, Release No. 34-37835, 63 SEC Docket 52, 58 (Oct. 17, 1996) (ruling that NASD disciplinary proceedings need not conform to 28 U.S.C. $\$ 2462$ 's five-year statute of limitations generally applicable in government proceedings where a sanction is sought). 
Lower courts have likewise described the SEC's role in SRO disciplinary proceedings as involving "adjudication."161

In resolving the constitutional questions presented in Free Enterprise Fund, the Supreme Court should consider the effect that its decision is likely to have on SROs such as FINRA and the NYSE. If the SRO model is one that provides for "a vast degree of Commission control at every significant step," 162 then SROs are essentially alter egos of the SEC, and most of their actions would constitute "state action" that is subject to the Constitution and possibly a host of federal statutes. If, however, the SRO model is one that provides for SEC oversight and enforcement authority, but nonetheless permits the SROs to operate with substantial discretion and autonomy, then under that model, the SROs, and by extension the PCAOB, cannot be said to be operating under the SEC's "extraordinary" direction and supervision. The Supreme Court can avoid effectively overturning decades of "state action" precedent by concluding that the D.C. Circuit has misconstrued the SRO model on which the PCAOB was patterned.

\section{The Nondelegation Doctrine}

The complaint in Free Enterprise Fund alleged that the PCAOB's structure suffered from three distinct constitutional infirmities: the Appointments Clause and separation of powers claims that are now before the Supreme Court, and a third claim of unconstitutional delegation. More specifically, this third claim alleged that Congress's "grant of wide-ranging authority to the Board" constituted an unconstitutional delegation of "legislative power to an entity outside of the Legislative Branch."163 The district judge granted the PCAOB summary judgment with respect to all three claims, ${ }^{164}$ and Petitioners opted to appeal only the Appointments Clause and separation of powers rulings. ${ }^{165}$ Given the fact that the Supreme Court has not

161. See, e.g., Jones v. SEC, 115 F.3d 1173, 1181 (4th Cir. 1997) (holding that neither the Fifth Amendment's Double Jeopardy clause nor collateral estoppel prevented the SEC from instituting its own enforcement action, because "as reviewer" of an NASD disciplinary proceeding, "the SEC does not become a party; its review role is an adjudicatory one").

162. Free Enterprise Fund, 537 F.3d at 683.

163. Complaint at $\uparrow 95$, Free Enterprise Fund v. Public Company Accounting Oversight Board, 2007 WL 891675 (D.D.C. Mar. 21, 2007).

164. See Free Enterprise Fund v. Public Company Accounting Oversight Board, 2007 WL 891675 (D.D.C. Mar. 21, 2007).

165. Free Enterprise Fund v. Public Company Accounting Oversight Board, 537 F.3d 667 (D.C. Cir. 2008). 
invalidated a federal statute on nondelegation grounds since $1936,{ }^{166}$ Petitioners' decision to abandon their nondelegation claim was undoubtedly a wise one. Yet the so-called "nondelegation doctrine" is essential to an understanding of why Congress structured the PCAOB in the way that it did, and therefore informs the Court's constitutional analysis under the Appointments Clause and the doctrine of separation of powers.

Congress routinely delegates to both public and private entities the power to make rules and set standards, and the modern constitutional constraints on such delegations are minimal. ${ }^{167}$ When applied to congressional grants of power to public entities, the nondelegation doctrine prohibits only those delegations that fail to articulate an "intelligible principle" to which the public entity must conform. ${ }^{168}$ Accordingly, modern courts have consistently held that Congress may vest federal agencies with vast rulemaking power, provided it is not "standardless." 169 Viewing the PCAOB as a federal entity, ${ }^{170}$ and quoting Sarbanes-Oxley's provision that PCAOB rules must be " "necessary or appropriate in the public interest or for the protection of investors," "171 the district court found that Congress provided " intelligible' standards" to guide the PCAOB in its rulemaking. ${ }^{172}$ The court therefore concluded that the "legislative delegation effected by the Act is squarely within the bounds of modern non-delegation doctrine."173

166. See A.L.A. Schechter Poultry Corp. v. United States, 295 U.S. 495 (1935); Carter v. Carter Coal Co., 298 U.S. 238 (1936); Panama Refinery Co. v. Ryan, 239 U.S. 388 (1936).

167. See, e.g., Gillian E. Metzger, Privatization as Delegation, 103 CoLUM. L. Rev. 1367, 1369 (2003) (observing that private entities "perform tasks that appear quintessentially governmental, such as promulgating standards or regulating third-party activities"); Jody Freeman, The Private Role in Public Governance, 75 N.Y.U. L. REv. 543, 547 (2000) (noting that "[a] variety of nongovernmental actors, including corporations, public interest organizations, private standard setting bodies, professional organizations, and nonprofit groups, engage in 'public' decision making in myriad ways").

168. See Whitman v. Am. Trucking Ass'n, 531 U.S. 457, 472 (2001) (emphasizing that Congress must articulate "an intelligible principle" to guide an agency's discretion when it delegates rulemaking authority to an administrative agency, but finding that the Clean Air Act did contain an "intelligible principle").

169. Id. at 473 (rejecting the D.C. Circuit Court's suggestion that an "agency can cure an unconstitutionally standardless delegation of power by declining to exercise some of that power").

170. See Free Enterprise Fund v. Public Co. Accounting Over. Bd., 2007 WL 891675 at *5 n.2 (2007) (stating that "the PCAOB will be considered a public entity for non-delegation analysis as well").

171. Id. at *5 (quoting 15 U.S.C. $§ 7213($ a)(1)).

172. Id. (holding that the Act's provisions "are 'intelligible' standards within the meaning of Whitman" and citing the Court's acknowledgment that it found "intelligible principles" in "various statutes authorizing regulation in the 'public interest'"); see Whitman, 531 U.S. at 474.

173. Free Enterprise Fund, WL 891675 at *5. Scholars have debated whether the Constitution's text and history supports such a doctrine. Compare Eric A. Posner \& Adrian Vermeule, Interring the Nondelegation Doctrine, 69 U.CHI. L. REV. 1721, 1722 (2002)(arguing that "there just is no constitutional 
Yet even if the district court had viewed the PCAOB as a private entity for purposes of the nondelegation doctrine, Congress's grant of power to the PCAOB undoubtedly would have survived constitutional scrutiny. Congressional delegations of rulemaking power to private entities raise substantial concerns about how that power will be utilized. As the Supreme Court observed in Carter Coal, "[t]his is legislative delegation in its most obnoxious form; for it is not even delegation to an official or official body, presumptively disinterested, but to private persons whose interests may be and often are adverse to the interests of others in the same business." 174 But the Supreme Court has made clear that governmental oversight of private decision-making will nonetheless insulate such congressional delegations from constitutional challenge. ${ }^{175}$ Accordingly, because no $P C A O B$ rule, disciplinary sanction, or "accounting support fee" can take effect over the SEC's objection, the Act's provision for SEC oversight would have shielded the PCAOB from "nondelegation" attack just as SEC oversight over rulemaking and discipline has insulated the NYSE and NASD from constitutional challenges on grounds of nondelegation. ${ }^{176}$

This so-called "private" nondelegation doctrine provides the most compelling explanation for why Congress structured the PCAOB in the way that it did. Recall Senator Gramm's statement that "[w]e want it to be private, but we want it to have governmental powers. We have tried to structure it in ways to try to accommodate this." 177 The SEC's oversight and enforcement

nondelegation rule, nor has there ever been"), with Larry Alexander \& Saikrishna Prakash, Reports of the Nondelegation Doctrine's Death Are Greatly Exaggerated, 70 U. CHI. L. REv. 1297 (2003) (advancing textual and historical arguments for the nondelegation doctrine). See also Gary Lawson, Delegation and Original Meaning, 88 VA. L. REv. 327, 330 (2002) ("The nondelegation doctrine . . is the Energizer Bunny of constitutional law: No matter how many times it gets broken, beaten, or buried, it just keeps on going and going."); Symposium, The Phoenix Rises Again: The Nondelegation Doctrine from Constitutional and Policy Perspectives, 20 CARdozo L. Rev. 731 (1999).

174. Carter v. Carter Coal Co., 298 U.S. 238, 311 (1936). The Court previously criticized a congressional delegation to private groups when it invalidated the National Recovery Act in A.L.A. Schechter Poultry Corp v. United States, 295 U.S. 495, 542 (1935).

175. See, e.g., Sunshine Anthracite Coal Co. v. Adkins, 310 U.S. 381, 398-400 (1940) (upholding a post-Carter Coal version of the Bituminous Coal Act that allowed private coal boards to set rules governing the sale of coal, with the board's rulemaking subject to approval, disapproval, or modification by the government's Bituminous Coal Commission).

176. See, e.g., R.H. Johnson \& Co. v. SEC, 198 F.2d 690 (2d Cir. 1965) (concluding that Exchange Act Section 15A did not constitute an unconstitutional delegation of power to the NASD because of the SEC's authority to disapprove NASD rules and review NASD disciplinary actions); Todd \& Co. v. SEC, 557 F.2d 1008, 1012-14 (3d Cir. 1977) (upholding delegation of broker-dealer registration because the NASD's rules and disciplinary actions "were subject to full review by the S.E.C., a wholly public body, which must base its decision on its own findings").

177. See supra note 23 and accompanying text (quoting statement of Sen. Gramm). 
authority over the PCAOB was a necessary "accommodation" because in the absence of such SEC authority, Congress's grant of rulemaking power to a "private" PCAOB would have been constitutionally doomed. Senator Gramm explicitly acknowledged this "accommodation" when he compared his and Senator Enzi's alternative board with the PCAOB: "[o]urs is a little more independent of the SEC; though in the end, to meet the constitutional test, the SEC had to have authority over it." 178 The private nondelegation doctrine is very likely the "constitutional test" to which Senator Gramm was referring.

The private nondelegation doctrine also provides a far more satisfactory answer to a question posed by the D.C. Circuit majority. Emphasizing the Act's "sweeping" provisions for SEC oversight and enforcement, the majority asked rhetorically: "why has Congress granted such pervasive Commission authority over the Board if not to preserve the means of Executive control?"179 But the majority's supposition that Congress sought to "preserve the means of Executive control" is undercut by Congress's mistaken impression that the PCAOB was not "an agency or establishment of the Federal Government."180 In all likelihood, Congress did not consider itself obligated to preserve "a means of Executive control" over the PCAOB. Nor is it likely that Congress considered itself restrained by the text of the Appointments Clause: ${ }^{181}$ the Act states explicitly that "[n]o member or person employed by ... the Board shall be deemed to be an officer or employee of or agent for the Federal Government by reason of such service."182

Congress was, however, acutely aware of the constitutional restraints on delegations to private regulators, and was understandably concerned that its delegation of vast rulemaking, adjudicative, and taxing authority to the PCAOB not run afoul of the Constitution. Thus, the control that Congress sought to preserve was largely legislative; neither Sarbanes-Oxley's text nor its legislative history evidence congressional concern with respect to executive control.

178. 148 CONG. REC. 12,120 (2002) (statement of Sen. Gramm) (emphasis added).

179. Free Enterprise Fund v. Public Company Accounting Oversight Board, 537 F.3d 667, 683 (D.C. Cir. 2008).

180. 15 U.S.C. $\$ 7211$ (b) (2006).

181. Cf. Walter Dellinger, The Constitutional Separation of Powers Between the President and Congress, 63 LAW \& CONTEMP. ProBS. 513, 535 (2000) (memorandum stating that "[t]he Appointments Clause simply is not implicated when significant authority is devolved upon non-federal actors").

182. 15 U.S.C. $\$ 7211$ (b). 


\section{Part Three: The Constitutional Analysis}

As I stated at the outset of this Article, the Free Enterprise Fund case envelops constitutional law in securities law. By examining the text of Sarbanes-Oxley and the events leading up to its passage, a clear "securities law" story emerges. Simply put, in creating the PCAOB as the accounting industry's overseer, Congress wanted it all: It wanted a strong, independent, private sector regulator with governmental powers, free from partisan forces and political influence. Yet Congress was unwilling to allow the accounting industry, working with the SEC, to establish its own regulator; nor was Congress willing to allow the private sector to select the new regulator's leadership. The Maloney Act model-culminating with the establishment of the NASD in 1938-allowed "too many issues to remain open to debate even after Congress has acted." ${ }^{183}$ So Congress established a strong, independent board appointed by the SEC, and subjected that board to oversight in certain well-delineated areas.

Constitutional law-the Constitution and the body of Supreme Court decisions interpreting the Constitution-tells us that Congress cannot have it all. As "the government itself," the PCAOB is subject to constitutional checks and balances, including the commands of the Appointments Clause and the doctrine of separation of powers. These checks and balances help to "ensure that those who wield[]" government power are "accountable to political force and the will of the people."184 These checks and balances also "allow[ ] the citizen to know who may be called to answer for making, or not making, those delicate and necessary decisions essential to governance."185

The PCAOB's structure and design accords the PCAOB substantial discretion and autonomy without imposing constitutionally sufficient accountability. Indeed, no elected official is directly responsible for appointing or removing the $\mathrm{PCAOB}$ members who promulgate rules, perform inspections, investigate suspected violations, prosecute firms and accountants, impose disciplinary sanctions, and levy taxes on public companies. Instead, the President appoints, and the Senate confirms, the SEC Commissioners who are charged with overseeing the PCAOB, with SEC Commissioners themselves insulated from presidential and congressional control to a significant degree. ${ }^{186}$

183. See supra text accompanying note 72 (quoting H.R. REP. No. 107-414, at 48 ).

184. Freytag v. Comm'r of Internal Revenue, 501 U.S. 868, 884 (1991).

185. Loving v. United States, 517 U.S. 748, 757-58 (1996).

186. See FCC v. Fox Television Stations, 129 S. Ct. 1800, 1829 (2009) (Breyer, J., dissenting) 
The pursuit of policy through PCAOB-like entities is worrisome because it places elected officials in a position where they will benefit regardless of the actual outcomes of those policies. That is, as I argued in my first article on the PCAOB, through the use of such doubly insulated regulators, "Congress and the President can claim credit for the ingenuity that resulted in regulatory successes and they can avoid blame for the ... regulator's unpopular decisions or unwise policies." ${ }^{187}$ But the general public ultimately loses under this scenario because blurred lines of accountability compromise the effective functioning of a representative democracy, and the more confusion that is created, "the lesser the likelihood that voters can express accurate preferences for retaining or removing elected officials." 188 The pursuit of policy through congressionally created "private" regulators like the PCAOB is all the more troubling because such "private" regulators may exercise vast regulatory power unfettered by the FOIA, APA, and other administrative statutes designed to curb administrative discretion and otherwise ensure that policymaking is rational, transparent, and accountable. ${ }^{189}$

This Article, of course, is incomplete absent a fuller discussion as to how the constitutional analysis is affected by a negative answer to the question posed by its title. If the PCAOB is not "a heavily controlled component" of the SEC, and if the Board's exercise of its statutory duties is not "subject to check by the Commission at every significant step," then its structure cannot be reconciled with the Supreme Court's Appointments Clause and separation of powers precedents. Section A explains why the PCAOB's five members are "principal" officers who, under the Appointments Clause, must be appointed by the President with advice and consent by the Senate. Section B explains why Congress's decision to vest the PCAOB appointment and removal power in the SEC violates the doctrine of separation of powers.

(observing that independent regulatory agencies possess "comparative freedom from ballot-box control" because they "enjoy an independence expressly designed to insulate them, to a degree, from "the exercise of political oversight"' (quoting Freytag v. Commissioner, 501 U.S. 868, 916 (Scalia, J., concurring in part and concurring in the judgment))).

187. Nagy, supra note 6, at 1065. See generally DAvid Schoenbrod, Power WITHout Responsiblity: How Congress Abuses the People Through Delegation (1993).

188. Nagy, supra note 6, at 1065. See also Jack M. Beermann, Privatization and Political Accountability, 28 FORDHAM URB. L.J. 1507, 1509 (2001) (stating that "the clarity of responsibility for an action or policy involves the degree to which the body politic can discern who in the political system is responsible for a decision, policy, or activity, so that efforts to exert political influence can be directed to the proper authorities").

189. Nagy, supra note 6 , at 1062 . 


\section{A. The Appointments Clause}

The Appointments Clause in Article II of the Constitution divides "Officers of the United States" into two categories: principal officers and inferior officers. ${ }^{190}$ Principal officers must be appointed by the President, subject to the "Advice and Consent of the Senate."191 In contrast, "Congress may by Law vest the Appointment of such inferior Officers, as they think proper, in the President alone, in the Courts of Law, or in the Heads of Departments." 192 As the Supreme Court emphasized in Edmond v. United States, ${ }^{193}$ the Appointments Clause "is more than a matter of "etiquette or protocol;' it is among the significant structural safeguards of the constitutional scheme." 194

Sarbanes-Oxley's provision for SEC appointment of the PCAOB's five members contravenes the plain text of the Appointments Clause because the members of the PCAOB do not qualify as "inferior" officers who may be appointed by the Head of a Department. According to Edmond: "[w]hether one is an 'inferior' officer depends on whether he has a superior." 195 SEC Commissioners who cannot remove PCAOB members in connection with even substantial disagreements about matters of policy can hardly qualify as the PCAOB's "superiors."196

Edmond further clarified that inferior officers "are officers whose work is directed and supervised at some level by others who were appointed by Presidential nomination with the advice and consent of the Senate." 197 Yet by channeling the SEC's oversight role toward the PCAOB's final rules and disciplinary sanctions, Congress ensured that the PCAOB would remain free to pursue its own policy preferences, particularly with respect to decisions relating to its rulemaking priorities as well as its investigative and enforcement determinations. As we saw in Part II of this Article, Congress viewed the Board's independence as essential to the success of the PCAOB's regulatory mission. ${ }^{198}$

190. U.S. Const., art. II, § 2, cl. 2.

191. Id.

192. Id.

193. 520 U.S. 651 (1997).

194. Id. at 659 (quoting Buckley v. Valeo, 424 U.S. 1, 125 (1976) (per curium)).

195. Id. at 662 .

196. See supra notes $82-83$ and accompanying text.

197. Edmond, 520 U.S. at 663.

198. See supra notes $127-35$ and accompanying text. 
Moreover, even if the D.C. majority were correct in its claim that the SEC has the power "to limit and to remove Board authority altogether,"199 this SEC power to sanction the PCAOB does not transform the SEC Commissioners into the Board members' "supervisors" while that power remains unexercised. Congress possesses an analogous power "to limit and to remove [SEC] authority altogether" through bicameral legislation-amendments to the federal securities laws or by withholding appropriations. Yet Congress's unexercised ability to limit the functions of the SEC, or its unexercised ability to abolish the agency entirely, does not make Congress the "supervisors" of the SEC's five Commissioners. Nor does the possibility that it could exercise its "at-will removal power over [SEC] functions" at some future point in time provide Congress with direction and supervision over the execution of the law. If it did, then the SEC and all other independent regulatory agencies subject to congressional oversight and appropriation would be unconstitutional under Bowsher v. Synar. ${ }^{200}$ In that decision the Court emphasized that " $[\mathrm{t}] \mathrm{he}$ Constitution does not contemplate an active role for Congress in the supervision of officers charged with the execution of the laws it enacts."201 Accordingly, the SEC's unexercised "at-will removal power over Board functions" cannot constitute constitutionally sufficient direction and supervision for purposes of the Appointments Clause.

In determining whether the PCAOB is "directed and supervised" by the SEC within the meaning of $E d m o n d$, the Supreme Court should also consider the SEC's own incentives for adhering to the congressional vision of a "strong, independent" PCAOB. If the SEC were to utilize its broad rulemaking authority under Sarbanes-Oxley to promulgate rules that resulted in "increased micromanaging of Board operations, ${ }^{, 202}$ Congress would likely view such action as an affront to the PCAOB's carefully constructed design. The fact that no such rules have been promulgated hardly comes as a surprise. Likewise, while Congress gave the SEC the responsibility to review and approve the PCAOB's budget and the "accounting support fee" that funds that budget, ${ }^{203}$ this theoretical "power of the purse" is tempered by Congress's ultimate control over the SEC's own purse. The value that Congress placed on the PCAOB's strength and independence serves as an important check on the

199. Free Enterprise Fund v. Public Company Accounting Oversight Board, 537 F.3d 667, 680 (D.C. Cir. 2008).

200. Bowsher v. Synar, 478 U.S. 714, 722 (1986).

201. Id.

202. Free Enterprise Fund, 537 F.3d at 676 n.6.

203. See supra notes 114-15 and accompanying text. 
SEC's exercise of its oversight responsibilities and, as a practical matter, ensures that the PCAOB does not operate with a "vast degree of Commission control at every significant step."204

In addition, the Supreme Court should consider the PCAOB's vast array of regulatory powers, and should contrast that to the powers that were at issue in other Appointments Clause cases, including Edmond and Morrison v. Olson. ${ }^{205}$ Edmond involved a challenge by service members to an affirmance of their court-martial conviction by the Coast Guard Court of Criminal Appeals, an intermediate judicial tribunal within the military justice system. ${ }^{206}$ These Coast Guard judges were appointed by the Secretary of Transportation and their powers were tied exclusively to their adjudicatory function. ${ }^{207}$ The Court found that the Coast Guard Judges were "inferior officers" because they had superiors and their "work [was] directed and supervised at some level by others" who were principal officers. ${ }^{208}$ Specifically, decisions by Coast Guard judges were subject to further review by the Court of Appeals for the Armed Forces, ${ }^{209}$ and Coast Guard judges were also subject to "administrative oversight" by the Coast Guard Judge Advocate General (JAG) who had the authority to remove a "[Coast Guard] judge from his judicial assignment without cause," and who was himself supervised by the Secretary of Transportation. ${ }^{210}$

Had Sarbanes-Oxley limited the PCAOB's regulatory authority to the conduct of disciplinary proceedings reviewable by the SEC, then PCAOB members could be said to be "directed and supervised" by the SEC within the meaning of Edmond. But as we have seen, PCAOB members also have significant rulemaking, investigative, and prosecutorial authority, and much of this policymaking discretion is insulated, by statutory design, from SEC control. ${ }^{211}$ Unlike the administrative oversight conducted by the Coast Guard

204. Free Enterprise Fund, 537 F.3d at 683.

205. 487 U.S. 654 (1988).

206. 520 U.S. 651,653 (1997).

207. Id. at 658.

208. Id. at 663 .

209. Id. at 665 . The Court acknowledged that the scope of review by the Court of Appeals for the Armed Forces was narrower than that exercised by the Coast Guard judges because facts were not reevaluated as long as there was some "competent evidence in the record to establish each element of the offense beyond a reasonable doubt." Id. Yet this limitation upon review did not render Coast Guard judges "principal officers." According to the Court, "what is significant is that [Coast Guard judges] have no power to render a final decision on behalf of the United States unless permitted to do so by other Executive officers." Id.

210. Id. at 664 (stating that "[t]he power to remove officers . . is a powerful tool for control").

211. See supra notes $127-35$ and accompanying text. 
JAG, Sarbanes-Oxley ensured that the SEC does not possess "the powerful tool" of at-will removal. ${ }^{212}$

Likewise, the independent counsel's investigative and prosecutorial authority at issue in Morrison v. Olson ${ }^{213}$ constitutes a subset of the powers assigned to the PCAOB in Sarbanes-Oxley. The independent counsel did not have the power to enact rules with the force of law for an entire profession, nor did she have the ability to adjudicate her own prosecutions. In evaluating her exclusively executive authority, and in reaching the conclusion that the independent counsel was an "inferior officer" who could properly be appointed by a "court of law," the Supreme Court relied on four factors: that she was subject to for-cause removal by "a higher Executive Branch official" (the Attorney General, who serves at the pleasure of the President) ${ }^{214}$ that she was empowered "to perform only certain, limited duties";"15 that her jurisdiction was narrow; ${ }^{216}$ and that her "office [was] limited in tenure."217 PCAOB members, in contrast, are removable only for-cause (defined restrictively) by SEC Commissioners who themselves are insulated from direct Presidential control. Moreover, PCAOB members have broad statutory duties that may be expanded even further by the SEC or the Board itself; ${ }^{218}$ they have jurisdiction over every registered public accounting firm and their associated persons; and they have tenure that extends for five years and not in any way tied to a particular person, investigation, or issue.

Finally, unlike either Edmond or Morrison, Free Enterprise Fund is not a case where the Supreme Court can simply defer to Congress's judgment that newly created federal officers are "inferior officers" within the meaning of the Appointments Clause. Rather, as emphasized previously, Sarbanes-Oxley states explicitly that no member of the PCAOB shall be deemed an "officer

212. See supra notes $86-87$ and accompanying text (discussing Sarbanes-Oxley's provisions limiting PCAOB member removal to instances of willful misconduct or unjustifiable transgressions).

213. Morrison v. Olson, 487 U.S. 654 (1988).

214. Id. at 671 .

215. Id. (observing that although the Act delegated to the independent counsel "full power and independent authority to exercise all investigative and prosecutorial functions and powers of the Department of Justice," the grant of authority “[did] not include any authority to formulate policy for the Government or Executive Branch ....").

216. The Court elaborated that "[ $n$ ]ot only is the Act itself restricted in applicability to certain federal officials suspected of certain serious federal crimes, but an independent counsel can act only within the scope of the jurisdiction that has been granted by the Special Division pursuant to a request by the Attomey General." Id. at 672.

217. Id. (emphasizing that the office was a temporary appointment "essentially to accomplish a single task [at the end of which] the office is terminated").

218. See supra note 29 (quoting 15 U.S.C. § 7211 (c)(5) (2006)). 
or employee of or agent for the Federal Government by reason of such service." 219 Congress was likely operating under the misimpression that PCAOB board members would be private sector officials akin to the officials who head the NYSE and the NASD (now FINRA). Thus, the task now falls directly on the Supreme Court to situate the PCAOB within the federal government. Both Sarbanes-Oxley's text and its legislative history command a finding that $\mathrm{PCAOB}$ members are principal officers who must be appointed by the President with advice and consent from the Senate.

\section{B. The Doctrine of Separation of Powers}

The constitutional doctrine of separation of powers is a structural safeguard that enforces the Framers' decision to "dispers[e] the federal power among the three branches - the Legislative, the Executive, and the Judicial ...."220 The doctrine ensures that one branch of government does not encroach on the duties and responsibilities of another branch, and that power is not aggrandized by one branch at the expense of another. ${ }^{221}$ As the Supreme Court has recognized, "[ $t]$ he ultimate purpose of this separation of powers is to protect the liberty and security of the governed."222 Accordingly, even if Congress and the President are comfortable with the manner in which the responsibility or power was redistributed, actions that violate the separation of powers doctrine must be declared unconstitutional. ${ }^{223}$

In structuring the PCAOB as an entity that is doubly insulated from partisan forces and political pressure, Congress impermissibly interfered with the President's Article II executive powers. Congress's unconstitutional interference is most evident in the Act's provision for five-year fixed terms with explicit limitations on the removal of PCAOB members. The Supreme Court made clear in Humphrey's Executor v. United States ${ }^{224}$ that Congress may create regulatory entities that exercise significant executive power, notwithstanding the fact that the officials who head those entities are insulated from direct presidential control by their fixed terms and limited removal. ${ }^{225}$

219. See supra text accompanying note 32 (quoting 15 U.S.C. $\$ 7211(\mathrm{~b})$ ).

220. Metro. Washington Airports Auth. v. Citizens for the Abatement of Aircraft Noise, 501 U.S. 252, 272 (1991).

221. Buckley v. Valeo, 424 U.S. 1, 122 (1976) (per curium).

222. Metro. Washington, 501 U.S. at 272.

223. INS v. Chadha, 462 U.S. 919, 942 n.13 (1983) (stating that " $[t]$ he assent of the Executive to a bill which contains a provision contrary to the Constitution does not shield it from judicial review").

224. Humphrey's Ex'r v. United States, 295 U.S. 602 (1935).

225. Id. See also Morrison v. Olson, 487 U.S. 654 (1988). 
But the officials who head those independent entities must be removable by the President for cause, ${ }^{226}$ or must be removable by an alter ego of the President for cause. ${ }^{227}$ As an independent regulatory agency whose commissioners serve for fixed terms, the SEC is itself insulated from presidential control to a substantial degree, and thus does not function as an "alter ego" of the President ${ }^{228}$ Moreover, even if SEC Commissioners could appropriately function as presidential surrogates, the statutory limitations on the SEC's ability to remove PCAOB members prevent the SEC from asserting meaningful control over the PCAOB's decisions regarding inspections, investigations, and enforcement actions. ${ }^{229}$ Accordingly, the statute's restrictive provisions for SEC-only removal of PCAOB members contravene both Humphrey's Executor and Morrison and provide "no means for the President to ensure the 'faithful execution' of the laws." 230

Like the Act's provision for SEC removal of PCAOB officials, Congress's decision to lodge the appointment power in the SEC further attenuates the President's control over the PCAOB, and thus further compromises the separation of powers. The SEC's power to appoint PCAOB officials deprives the President of the ability to choose like-minded members who share his policy goals and preferences. As the current Solicitor General recognized in a 2001 article, "[a]s a practical matter, successful insulation of administration from the President-even if accomplished in the name of 'independence'-will tend to enhance Congress's own authority over the insulated activities." ${ }^{\text {"231 }}$ Thus, while the Act's provisions for the appointment and removal of PCAOB members do not constitute direct congressional aggrandizement of power, these provisions nonetheless produce that effect.

Under Humphrey's Executor and Morrison, the Constitution does not prohibit Congress from enhancing its power through the creation of independent regulatory agencies like the SEC. However, the Supreme Court should not extend those decisions to allow Congress to accumulate even more power through the creation of a regulator such as the PCAOB that is further

226. Humphrey's Ex'r, 295 U.S. at 625-26.

227. See Morrison, 487 U.S. at 692 (stating that "because the independent counsel may be terminated for 'good cause,' the Executive, through the Attorney General, retains ample authority to assure that the counsel is completely performing his or her statutory responsibilities in a manner that comports with the provisions of the Act").

228. See Humphrey's Ex'r, 295 U.S. at 628 (stating that independent agencies "cannot in any proper sense be characterized as an arm or an eye of the executive").

229. See supra notes $86-87$ and accompanying text.

230. Morrison, 487 U.S. at 692.

231. Elena Kagan, Presidential Administration, 114 HARv. L. ReV. 2245, 2271 n.93 (2001). 
detached from Presidential appointment and removal. Constitutional clashes over the doctrine of separation of powers are often couched as debates between formalists (emphasizing a "unitary executive" model of the Presidency) and functionalists (emphasizing the ultimate balance of power, rather than its strict separation). ${ }^{232}$ Yet with respect to the PCAOB, even functionalists have good reason to conclude that the structural design of the PCAOB is a bridge too far.

\section{ConcLusion}

Although Congress did not intend to do so, when it created the PCAOB as an accounting industry regulator with an SEC-appointed board, Congress created a federal entity that is "part of the Government" ${ }^{\text {"233 }}$ for purposes of the Constitution, including the commands of the Appointments Clause and principles of separation of powers. The PCAOB's doubly insulated design is constitutionally flawed because it allows the PCAOB to escape such checks and balances.

If the Supreme Court declares the PCAOB unconstitutional, Congress should act quickly to redesign the PCAOB, either as a true component of the SEC, or as an independent regulatory agency with members who are appointed by the President with advice and consent of the Senate, and removable for cause by the President. Either alternative will result in an entity that is substantially less "strange." But that new PCAOB will be one that is far more in keeping with the democratic values embodied in the text and structure of the Constitution.

232. See generally Peter L. Strauss, Formal and Functional Approaches to Separation-of-Powers Questions-A Foolish Inconsistency?, 72 CORNELL L. REV. 488 (1987).

233. Lebron, 513 U.S. at 400. 